\title{
Ice nucleating particles at a coastal marine boundary layer site: correlations with aerosol type and meteorological conditions
}

\author{
R. H. Mason ${ }^{1}$, M. Si ${ }^{1}$, J. Li ${ }^{2}$, C. Chou ${ }^{1}$, R. Dickie ${ }^{1}$, D. Toom-Sauntry ${ }^{3}$, C. Pöhlker ${ }^{4}$, J. D. Yakobi-Hancock ${ }^{5}$, \\ L. A. Ladino ${ }^{5}$, K. Jones ${ }^{6}$, W. R. Leaitch ${ }^{3}$, C. L. Schiller ${ }^{6}$, J. P. D. Abbatt ${ }^{5}$, J. A. Huffman ${ }^{2}$, and A. K. Bertram ${ }^{1}$ \\ ${ }^{1}$ Department of Chemistry, University of British Columbia, Vancouver, BC, V6T1Z1, Canada \\ ${ }^{2}$ Department of Chemistry and Biochemistry, University of Denver, Denver, CO, 80208, USA \\ ${ }^{3}$ Climate Research Division, Environment Canada, Toronto, ON, M3H5T4, Canada \\ ${ }^{4}$ Biogeochemistry Department, Max Planck Institute of Chemistry, Mainz, 55020, Germany \\ ${ }^{5}$ Department of Chemistry, University of Toronto, Toronto, ON, M5S3H6, Canada \\ ${ }^{6}$ Air Quality Science Unit, Environment Canada, Vancouver, BC, V6C3S5, Canada
}

Correspondence to: A. K. Bertram (bertram@chem.ubc.ca) and J. A. Huffman (alex.huffman@du.edu)

Received: 10 May 2015 - Published in Atmos. Chem. Phys. Discuss.: 16 June 2015

Revised: 9 October 2015 - Accepted: 18 October 2015 - Published: 10 November 2015

\begin{abstract}
Information on what aerosol particle types are the major sources of ice nucleating particles (INPs) in the atmosphere is needed for climate predictions. To determine which aerosol particles are the major sources of immersion-mode INPs at a coastal site in Western Canada, we investigated correlations between INP number concentrations and both concentrations of different atmospheric particles and meteorological conditions. We show that INP number concentrations are strongly correlated with the number concentrations of fluorescent bioparticles between -15 and $-25^{\circ} \mathrm{C}$, and that the size distribution of INPs is most consistent with the size distribution of fluorescent bioparticles. We conclude that biological particles were likely the major source of ice nuclei at freezing temperatures between -15 and $-25^{\circ} \mathrm{C}$ at this site for the time period studied. At $-30^{\circ} \mathrm{C}$, INP number concentrations are also well correlated with number concentrations of the total aerosol particles $\geq 0.5 \mu \mathrm{m}$, suggesting that non-biological particles may have an important contribution to the population of INPs active at this temperature. As we found that black carbon particles were unlikely to be a major source of ice nuclei during this study, these nonbiological INPs may include mineral dust. Furthermore, correlations involving chemical tracers of marine aerosols and marine biological activity, sodium and methanesulfonic acid, indicate that the majority of INPs measured at the coastal site likely originated from terrestrial rather than marine sources. Finally, six existing empirical parameterizations of ice nucle-
\end{abstract}

ation were tested to determine if they accurately predict the measured INP number concentrations. We found that none of the parameterizations selected are capable of predicting INP number concentrations with high accuracy over the entire temperature range investigated. This finding illustrates that additional measurements are needed to improve parameterizations of INPs and their subsequent climatic impacts.

\section{Introduction}

The formation of ice in the atmosphere can occur by two primary mechanisms: homogeneous and heterogeneous ice nucleation. Homogeneous nucleation can only occur at temperatures below approximately $-37^{\circ} \mathrm{C}$. However, heterogeneous nucleation can occur at all temperatures below $0^{\circ} \mathrm{C}$. In the atmosphere, heterogeneous nucleation occurs on solid or partially solid aerosol particles termed ice nucleating particles (INPs). INPs are a small subset of the total aerosol population (Rogers et al., 1998) whose unique surface properties make them capable of lowering the energy barrier to ice nucleation and hence cause freezing at warmer temperatures or lower supersaturations with respect to ice compared to homogeneous nucleation. Four modes of nucleation have been identified (Vali, 1985; Vali et al., 2015): deposition nucleation, where ice forms on the INP directly from the gas phase; condensation freezing, where ice forms during 
the condensation of water onto the INP; immersion freezing, where ice forms on an INP within a supercooled droplet; and contact freezing, where the impact of a supercooled droplet by an INP initiates freezing. In this study we focus on immersion freezing, which is relevant to ice formation in mixedphase clouds.

The presence of INPs in the atmosphere can lead to changes in the microphysical properties and lifetime of clouds. As a result, a change in INP concentrations can indirectly modify climate by changing cloud optical properties, lifetime, and cloud extent (e.g., Baker, 1997; Lohmann, 2002; Storelvmo et al., 2011; Creamean et al., 2013). Currently, the role of INPs in climate change is highly uncertain (Boucher et al., 2013). To predict the role of INPs in climate change and precipitation, information on what particle types are the major sources of INPs in the atmosphere is needed. Possible candidates for INPs in the atmosphere include mineral dust, primary biological particles, and black carbon (BC). Primary biological INPs are believed to be dominant above $-15^{\circ} \mathrm{C}$ while below this temperature nonbiological INPs may be of greater importance (Murray et al., 2012).

Mineral dust particles have long been known to be efficient INPs (Mason and Maybank, 1958). Numerous laboratory studies have found that different types of mineral dust particles can effectively nucleate ice in both the immersion and deposition modes, for example kaolinite (Lüönd et al., 2010; Wheeler and Bertram, 2012), Arizona test dust (Kanji and Abbatt, 2010; Knopf and Koop, 2006; Marcolli et al., 2007; Niedermeier et al., 2010), NX illite (Broadley et al., 2012), natural Asian and Saharan dust samples (Field et al., 2006; Kulkarni and Dobbie, 2010), and more recently feldspar (Atkinson et al., 2013; Yakobi-Hancock et al., 2013). Both field studies (DeMott et al., 2003; Cziczo et al., 2004; Richardson et al., 2007; Klein et al., 2010; Chou et al., 2011; Creamean et al., 2013) and modeling studies (Hoose et al., 2010b) also suggest that mineral dust can be a dominant INP in the atmosphere.

Primary biological particles have also been identified as a possible source of INPs (e.g., Szyrmer and Zawadzki, 1997; Möhler et al., 2007; Garcia et al., 2012; Hiranuma et al., 2015). The ocean and continents are both potential sources of ice-active primary biological particles (Hoose and Möhler, 2012; Murray et al., 2012). Model studies have shown that biological particles may not be important for ice nucleation on a global and annual scale (Hoose et al., 2010a; Sesartic et al., 2013; Spracklen and Heald, 2014) but may be important on regional and seasonal scales, especially if concentrations of biological particles are high or concentrations of other types of INPs are low (Phillips et al., 2009; Sun et al., 2012; Burrows et al., 2013; Creamean et al., 2013; Yun and Penner, 2013; Costa et al., 2014; Spracklen and Heald, 2014).

Ice-active biological particles from continental sources include bacteria (e.g., Maki et al., 1974; Lindow et al., 1978; Maki and Willoughby, 1978; Kozloff et al., 1983), fungal spores (e.g., Jayaweera and Flanagan, 1982; Tsumuki et al., 1992; Richard et al., 1996; Iannone et al., 2011; Haga et al., 2013; Morris et al., 2013), and pollen (e.g., Diehl et al., 2001, 2002; von Blohn et al., 2005; Pummer et al., 2012; Augustin et al., 2013; Hader et al., 2014; O'Sullivan et al., 2015). In addition, strong correlations between number concentrations of INPs and primary biological particles have been found during studies in the Amazon and United States in forested regions (Prenni et al., 2009, 2013; Huffman et al., 2013; Tobo et al., 2013). Ice-active biological particles have also been observed at high concentrations above a corn field during combine harvesting (Garcia et al., 2012). Biological particles have been observed in ice-crystal residuals of mixed-phase clouds (e.g., Pratt et al., 2009), cloud water (e.g., Joly et al., 2014), and snow samples (e.g., Christner et al., 2008; Morris et al., 2008; Hill et al., 2014), and ice-active biological particles have also been associated with soils (Conen et al., 2011; O’Sullivan et al., 2014; Tobo et al., 2014; Fröhlich-Nowoisky et al., 2015).

Biological material found in the ocean that may be a source of INP in the atmosphere include phytoplankton, bacteria, and biological material in the sea surface microlayer. Studies have indicated that bacteria and phytoplankton found in seawater and sea ice are a potential source of INPs in the atmosphere (Schnell, 1975, 1977; Schnell and Vali, 1975; Jayaweera and Flanagan, 1982; Parker et al., 1985; Alpert et al., 2011; Knopf et al., 2011). Material in the sea surface microlayer has also been found to exhibit ice activity (Wilson et al., 2015), and previous work has indicated that biological material generated during phytoplankton blooms may be a source of INPs in the atmosphere (Prather et al., 2013; DeMott et al., 2015). The modeling work of Burrows et al. (2013) indicates that ice-active primary biological particles from the ocean may be particularly important in remote regions such as the Southern Ocean.

BC particles are another potential type of INP in the atmosphere (Kärcher et al., 2007). Field studies have produced varying results on the relative importance of these particles as a source of ice nuclei in the atmosphere (e.g., Lin et al., 2006; Cozic et al., 2008; Kamphus et al., 2010; Twohy et al., 2010; Ebert et al., 2011; Corbin et al., 2012; Cziczo et al., 2013; Knopf et al., 2014; McCluskey et al., 2014). Laboratory studies suggest that the ability of BC particles to act as INPs may depend strongly on the method of generating these particles, such as the fuel type (e.g., Diehl and Mitra, 1998; Gorbunov et al., 2001; Möhler et al., 2005; Dymarska et al., 2006; Kärcher et al., 2007; DeMott et al., 2009; Petters et al., 2009; Friedman et al., 2011; Cziczo et al., 2013; Brooks et al., 2014). For example, the combustion of some biomass fuels emits more efficient INPs when compared to the combustion of some fossil fuels (e.g., Petters et al., 2009; McCluskey et al., 2014). BC is generally considered to be less efficient than mineral dust in the immersion mode (Hoose and Möhler, 2012; Murray et al., 2012; and references therein). Models have suggested that carbonaceous aerosols may have a 
significant indirect effect on climate if they efficiently nucleate ice (e.g., Lohmann, 2002; Liu et al., 2009; Penner et al., 2009; Yun and Penner, 2013).

To determine which aerosol particles are the major source of INPs in the immersion mode at a coastal site in western Canada, we investigate correlations between INP number concentrations and both concentrations of different atmospheric particle types and meteorological conditions. Measurements were conducted in August 2013 as part of the NETwork on Climate and Aerosols: addressing key uncertainties in Remote Canadian Environments (NETCARE) project (http://netcare-project.ca/). A primary goal of the study was to investigate whether primary biological particles and $\mathrm{BC}$ particles are major sources of INPs at this site and determine if the ocean contributes to the measured INP population. In addition, we also test the ability of parameterizations reported in the literature at predicting the INP number concentrations measured at this coastal site.

\section{Methods}

\subsection{Site description and instrument location}

Measurements were performed at Amphitrite Point $\left(48.92^{\circ} \mathrm{N}, 125.54^{\circ} \mathrm{W}\right)$ on the west coast of Vancouver Island in British Columbia, Canada. This was also the location of studies on ozone (McKendry et al., 2014) and cloud condensation nuclei (Yakobi-Hancock et al., 2014). Amphitrite Point (Fig. 1) is located approximately $2.2 \mathrm{~km}$ south of the town of Ucluelet (population of 1627 in 2011; Statistics Canada, 2012). The largest nearby population centers are Nanaimo $120 \mathrm{~km}$ to the east, Victoria $170 \mathrm{~km}$ to the southeast, and Vancouver $180 \mathrm{~km}$ to the east. This region has a temperate maritime climate, characterized by warm summers, mild winters, and relatively high levels of cloud cover and precipitation. According to the Köppen-Geiger classification scheme (Kottek et al., 2006), the climate type is $\mathrm{Cfb}$, which denotes a mild midlatitude and moist climate (C) with no dry season (f), and a moderate summer where the average hottest-month temperature is $\angle 22^{\circ} \mathrm{C}$ and at least 4 months have an average temperature $>10^{\circ} \mathrm{C}$ (b). Local forests contain predominantly coniferous tree species including western hemlock, western redcedar, and Douglas fir that is characteristic of most low-elevation sites along the west coast of Canada (Austin et al., 2008). The Pacific Ocean is west and south of the site, where the mixing of iron-rich coastal waters with nitrate-rich oceanic waters produces a zone of high primary productivity (Whitney et al., 2005; Ribalet et al., 2010). Measurements were carried out from 6 to 27 August 2013. Specifics on the sampling times (i.e., start and end times) are given in Table S1 in the Supplement.

Aerosol instrumentation was located in one of two mobile laboratories; one specific to the NETCARE project (labeled

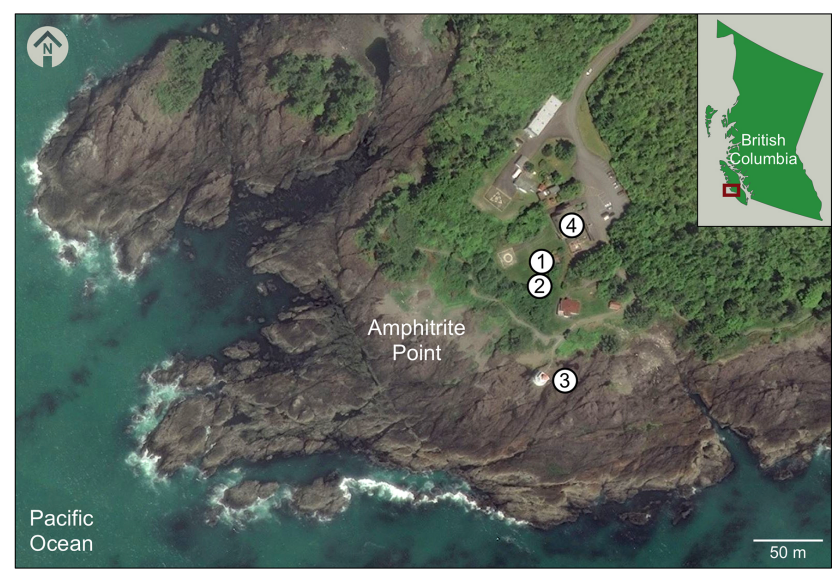

Figure 1. A satellite image of the sampling site: (1) location of the MOUDIs and the WIBS-4A, (2) location of the MAAP, (3) Amphitrite Lighthouse where most meteorological data was collected, and (4) a station of the Canadian Coast Guard with supporting infrastructure. The image was modified from Bing Maps, 2014 (http://www.bing.com/maps/). Inset: the location of the sampling site in British Columbia, Canada.

1 in Fig. 1) and one operated by Environment Canada, the British Columbia Ministry of Environment, and Metro Vancouver (labeled 2 in Fig. 1). Aerosols were sampled through louvered total suspended particulate inlets (Mesa Labs Inc., Butler, NJ, USA) or louvered $\mathrm{PM}_{10}$ inlets (Thermo Scientific, Waltham, MA, USA) atop masts extending $5.5 \mathrm{~m}$ a.g.1. The two mobile laboratories were approximately $20 \mathrm{~m}$ above mean sea level and $100 \mathrm{~m}$ from the high tide line of the $\mathrm{Pa}$ cific Ocean (McKendry et al., 2014). A row of trees and shrubs approximately $2-10 \mathrm{~m}$ in height stood between the laboratories and the rocky shoreline. Adjacent to the laboratories, on their seaward side, were the Amphitrite Lighthouse (labeled 3 in Fig. 1) and the Wild Pacific Trail, local tourist attractions and a source of foot traffic during fair weather. Immediately north and east of the site was a station of the Canadian Coast Guard (labeled 4 in Fig. 1).

The majority of the meteorological parameters reported in this study were measured at Amphitrite Lighthouse, located approximately halfway between the mobile laboratories and the ocean. Relative humidity and temperature were monitored using an HMP45C probe (Campbell Scientific, Logan, UT, USA) with accuracies of $\pm 3 \%$ and $\pm 0.2{ }^{\circ} \mathrm{C}$, respectively. Wind direction and wind speed were determined by a model 05305L Wind Monitor (R. M. Young, Traverse City, Michigan, USA) to a respective accuracy of $\pm 3^{\circ}$ and $\pm 0.2 \mathrm{~m} \mathrm{~s}^{-1}$. Measurements of wind speed were also obtained from a moored buoy located in La Perouse Bank, approximately $35 \mathrm{~km}$ to the WSW of the Amphitrite Point sampling site (station $46206 ; 48.84^{\circ} \mathrm{N}, 126.00^{\circ} \mathrm{W}$; National Data Buoy Center, 2013). The cup anemometer used to measure wind speed on the buoy was positioned at $5 \mathrm{~m}$ a.s.1. 


\subsection{Ice nucleating particle measurements}

INP number concentrations in the immersion mode were determined using the micro-orifice uniform deposit impactordroplet freezing technique (MOUDI-DFT; Mason et al., 2015). A Model II 120R MOUDI (MSP Corp., Shoreview, MN, USA) collected size-fractionated aerosol samples by inertial separation (Marple et al., 1991) onto hydrophobic glass cover slips (HR3-215; Hampton Research, Aliso Viejo, CA, USA). To compensate for the thickness of the hydrophobic glass cover slips, spacers were placed between the MOUDI stages. Custom substrate holders were added to the MOUDI impaction plates to maintain consistent positioning of the hydrophobic glass cover slips within the impactor (Mason et al., 2015). Samples from MOUDI stages 2-8 were used in this study, corresponding to a particle size range of $0.18-$ $10 \mu \mathrm{m}$ ( $50 \%$ cutoff aerodynamic diameter). Thirty-four sets of MOUDI samples were collected; 18 during the day and 16 at night. The average collection time of a MOUDI sample was $7.8 \mathrm{~h}$. Details of each INP sampling period are available in Table $\mathrm{S} 1$.

The ice-nucleating ability of particles collected by the MOUDI was then determined by the droplet freezing technique (DFT; Koop et al., 2000; Iannone et al., 2011; Mason et al., 2015; Wheeler et al., 2015). Within $24 \mathrm{~h}$ of collection, samples were placed in a temperature- and humiditycontrolled flow cell that was coupled to an optical microscope (Axiolab; Zeiss, Oberkochen, Germany) with a $5 \times$ magnification objective. At a sample temperature of $0{ }^{\circ} \mathrm{C}$ a humidified gas flow was introduced, resulting in the formation of water droplets on the sample. Following droplet growth by condensation and coalescence, the droplet size was decreased with a dry gas flow to a final size of approximately $80-160 \mu \mathrm{m}$ in diameter. On average, more than $99 \%$ of particles on the surface of the hydrophobic glass cover slip were incorporated into droplets by this procedure. Closing valves upstream and downstream of the cell then isolated the flow cell, and the sample temperature was lowered at a constant rate of $-10^{\circ} \mathrm{C} \mathrm{min}^{-1}$ to $-40^{\circ} \mathrm{C}$. This cooling rate was chosen to minimize the freezing of a liquid droplet by contact with a growing ice crystal. Recent work suggests that changing the cooling rate by an order of magnitude may lead to a shift in freezing temperatures of approximately $0.5-2{ }^{\circ} \mathrm{C}$ (Murray et al., 2011; Broadley et al., 2012; Welti et al., 2012; Wright and Petters, 2013; Wright et al., 2013; Wheeler et al., 2015). During droplet growth, evaporation, and cooling, a CCD camera connected to the optical microscope recorded a digital video of the sample. Using the video timestamp and a resistance temperature detector positioned within the flow cell, which was calibrated against the melting point of water droplets approximately $100 \mu \mathrm{m}$ in diameter, the freezing temperature of each droplet was found by manually noting the increase in droplet opacity immediately following ice nucleation.
Since a small fraction of the sampled particles (less than $1 \%$ on average) was not included in the droplets, there was the possibility of deposition nucleation as well. However, based on an analysis of the videos recorded during the ice nucleation experiments, fewer than $3 \%$ of all freezing events observed were the result of deposition nucleation. Due to the low occurrence of deposition nucleation, only immersion freezing results are reported.

The atmospheric number concentration of INPs within the size cut of each MOUDI stage, [INPs $(T)]$, was evaluated using the following equation:

$[\operatorname{INPs}(T)]=-\ln \left(\frac{N_{\mathrm{u}}(T)}{N_{o}}\right) N_{o}\left(\frac{A_{\text {deposit }}}{A_{\mathrm{DFT}} V}\right) f_{\text {nu }} f_{\text {ne }}$,

where $N_{\mathrm{u}}(T)$ is the number of unfrozen droplets at temperature $T, N_{o}$ is the total number of droplets, $A_{\text {deposit }}$ is the total area of the sample deposit on the MOUDI impaction plate, $A_{\mathrm{DFT}}$ is the area of the sample analyzed by the DFT, $V$ is the volume of air sampled by the MOUDI, $f_{\text {nu }}$ is a correction factor to account for changes in particle concentration across each MOUDI sample (because the DFT analyzes only a fraction of the entire sample), and $f_{\text {ne }}$ is a correction factor to account for the uncertainty associated with the number of nucleation events in each experiment following Koop et al. (1997). Additional details are available in Mason et al. (2015). Equation (1) takes into account the possibility of multiple INPs being contained in a single droplet using the method of Vali (1971). The total INP number concentration was found by summing the INP number concentrations over all analyzed MOUDI stages. Here we report INP data between -15 and $-30^{\circ} \mathrm{C}$ as few $(1.3 \%)$ droplets froze at temperatures $>-15^{\circ} \mathrm{C}$, whereas in some experiments all droplets were frozen at temperatures $<-30^{\circ} \mathrm{C}$, which prohibited the calculation of INP number concentrations by Eq. (1). INP number concentrations have been adjusted to standard temperature and pressure.

\subsection{Total and fluorescent aerosol measurements with sizes $\geq 0.5 \mu \mathrm{m}$}

A model-4A waveband integrated bioaerosol sensor (WIBS4A; Droplet Measurement Technologies, Boulder, CO, USA) was used to find both the total and fluorescent aerosol number concentrations with sizes $\geq 0.5 \mu \mathrm{m}$. Particles that enter the WIBS-4A first transect a continuous-wave $635 \mathrm{~nm}$ diode laser. The forward-scattered light from the continuous-wave laser is detected with a quadrant photomultiplier tube for the determination of particle size and asymmetry factor based on the signal intensity and asymmetry, respectively. The detected forward-scattered light also triggers excitation pulses from xenon lamps, the first at a wavelength of $280 \mathrm{~nm}$ and the second at $370 \mathrm{~nm}$. The excitation pulses may lead to fluorescent emission from the particle, which is then collected in two wavelength ranges: $310-400 \mathrm{~nm}$ (short wavelength region) and 420-650 nm (long wavelength region). This results 
in sample information provided for each particle in three fluorescence channels: excitation at $280 \mathrm{~nm}$, emission in the short wavelength region (FL1); excitation at $280 \mathrm{~nm}$, emission in the long wavelength region (FL2); and excitation at $370 \mathrm{~nm}$, emission in the long wavelength region (FL3). Detailed descriptions of the instrument can be found in Kaye et al. (2005), Gabey et al. (2010), and Healy et al. (2012a). The sample and total flow rates of the WIBS-4A were 0.63 and $2.3 \mathrm{~L} \mathrm{~min}^{-1}$, respectively, and number concentrations have been adjusted to standard temperature and pressure.

The fluorescent channels used in the WIBS-4A allow for the detection of fluorophores characteristic of biological activity. These fluorophores include the amino acid tryptophan, the cofactor $\mathrm{NAD}(\mathrm{P}) \mathrm{H}$, and the micronutrient riboflavin. While some non-biological species such as soot, mineral dusts, polycyclic aromatic hydrocarbons, secondary organic aerosols, and humic-like substances can produce a fluorescent signal (Pan et al., 1999; Sivaprakasam et al., 2004; Bones et al., 2010; Gabey et al., 2011; Pöhlker et al., 2012; Lee et al., 2013), the number of fluorescent particles is generally considered to be a lower limit to the number of primary biological particles (Huffman et al., 2010, 2012; Pöhlker et al., 2012). In addition, fluorescence microscopy measurements of samples collected during this field study show high concentrations of fluorescent biological particles (see below). Therefore, fluorescent particles detected using the WIBS-4A are hereafter referred to as fluorescent bioparticles.

Although the WIBS was used to determine the total and fluorescent aerosol number concentrations with sizes $\geq 0.5 \mu \mathrm{m}$, it should be noted that the counting efficiency of the WIBS for polystyrene latex spheres with particle diameters of $0.5 \mu \mathrm{m}$ is roughly $50 \%$ (Healy et al., 2012b). Hence, the concentration of particles reported here in the $0.5-1 \mu \mathrm{m}$ size range should be considered as the lower limits.

\subsection{Fluorescence microscopy}

Aerosol samples were collected onto glass cover slips using a custom single-stage impactor operating at a flow rate of $1.2 \mathrm{~L} \mathrm{~min}^{-1}$ with a $50 \%$ cutoff aerodynamic diameter of $0.5 \mu \mathrm{m}$. Prior to sample collection, the substrates were coated with a thin layer of high viscosity grease (Baysilone grease, Bayer, Germany) to reduce particle bounce.

Fluorescence microscopy images were taken on a BZ9000 fluorescence microscope (Keyence, Inc., Osaka, Japan) equipped with a $120 \mathrm{~W}$ super high-compression mercury lamp and a 1.5-megapixel monochrome CCD camera. Images were obtained using the following fluorescence filters: OP-66834 DAPI-BP $\left(\lambda_{\mathrm{ex}}=360 / 20 \mathrm{~nm}, \lambda_{\text {dichroic }}=400 \mathrm{~nm}\right.$, $\left.\lambda_{\mathrm{abs}}=460 / 25 \mathrm{~nm}\right)$, OP-66836 GFP-BP $\left(\lambda_{\mathrm{ex}}=470 / 20 \mathrm{~nm}\right.$, $\left.\lambda_{\text {dichroic }}=495 \mathrm{~nm}, \quad \lambda_{\text {abs }}=535 / 25 \mathrm{~nm}\right), \quad$ and OP- 66838 Texas Red $\quad\left(\lambda_{\text {ex }}=560 / 20 \mathrm{~nm}, \quad \lambda_{\text {dichroic }}=595 \mathrm{~nm}\right.$, $\left.\lambda_{\text {abs }}=630 / 30 \mathrm{~nm}\right)$. Filter specifications are given as wavelength of maximum absorbance or excitation and full width at half maximum $(\lambda / \mathrm{FWHM})$.

\subsection{Black carbon (BC) measurements}

BC mass concentrations were measured using a multi-angle absorption photometer (MAAP model 5012; Thermo Scientific, Franklin, MA, USA). Detailed descriptions of the MAAP are available in Petzold et al. (2002), Petzold and Schönlinner (2004), and Petzold et al. (2005). Within the MAAP, particles are continuously collected on a glass fiber filter. The intensity of transmitted and forward-scattered light through the aerosol particle layer and filter matrix is measured by a photodetector located beneath the filter at a frequency of $1 \mathrm{~Hz}$. The signal strength is attenuated by the presence of both light-absorbing particles and particles that cause backscattering. As the angular distribution of backscattered light is related to the fraction of non-absorbing particles (Petzold and Schönlinner, 2004), four additional photodetectors located above the filter are used to quantify the non-absorbing component of the sample. The absorbance by the collected aerosol is then related to a mass of BC using a mass-specific absorption coefficient of $6.6 \mathrm{~m}^{2} \mathrm{~g}^{-1}$. Mass concentrations have been adjusted to standard temperature and pressure.

Non-BC material such as mineral dust and brown carbon can also absorb $670 \mathrm{~nm}$ wavelength light used in the MAAP, albeit with smaller absorption coefficients than BC (Yang et al., 2009). We follow the recommendation of Petzold et al. (2013) for BC data derived from optical absorption methods and hereafter refer to MAAP data as measurements of equivalent black carbon (eBC).

\subsection{Tracers of anthropogenic aerosols}

Measurements of $\mathrm{CO}, \mathrm{NO}_{x}$, and $\mathrm{SO}_{2}$ were used to identify anthropogenic contributions to the sampled air masses as sources of these gases include fossil fuel combustion and biomass burning (Galanter et al., 2000; Gadi et al., 2003; United States Environmental Protection Agency, 2014). CO concentrations were monitored using a Thermo Fisher Scientific 48i-TL, an absorbance-based analyzer using infrared light at a wavelength of $4.6 \mu \mathrm{m}$. $\mathrm{NO}_{x}$ concentrations were monitored using chemiluminescence with a Thermo Fisher Scientific 42i. This instrument first converts $\mathrm{NO}_{2}$ to $\mathrm{NO}$ which then reacts with ozone to produce luminescence of intensity in proportion to the level of $\mathrm{NO}_{x}$. A Teledyne API T100U, using fluorescence emitted by $\mathrm{SO}_{2}$ under excitation by ultraviolet light, monitored $\mathrm{SO}_{2}$ concentrations. Data were collected for each instrument at a frequency of $1 \mathrm{~min}^{-1}$.

\subsection{Ion measurements}

Size-resolved aerosol samples were collected on Teflon ${ }^{\circledR}$ filters (Pall Corporation, Port Washington, NY, USA) using a second MOUDI (model 110R). Samples were collected 
on the inlet, stage 1 , and stages $7-10$ of the MOUDI with stages $2-6$ being removed prior to collection. The flow rate through the MOUDI was on average $24 \mathrm{~L} \mathrm{~min}^{-1}$, resulting in a collected size range of 0.068 to $>20 \mu \mathrm{m}$ ( $50 \%$ cutoff aerodynamic diameter). Collection times ranged from approximately 45 to $49 \mathrm{~h}$ and samples were stored at $4{ }^{\circ} \mathrm{C}$ for a period of 1 month before analysis.

Mass concentrations of sodium and methanesulfonic acid (MSA) were found using cationic and anionic chromatography following the method of Phinney et al. (2006). Briefly, filters were extracted by sonication in $10 \mathrm{~mL}$ of deionized water for $1 \mathrm{~h}$, and samples were analyzed with a Dionex DX600 ion chromatograph using an AS11-HC column and a CS12 column for anions and cations, respectively. Filter blanks were measured to be below the limit of detection for both analytes. Mass concentrations were adjusted to standard temperature and pressure.

\subsection{Back trajectories}

Back trajectories spanning a period of $72 \mathrm{~h}$ were calculated for each sampling period using the Hybrid Single-Particle Lagrangian Integrated Trajectory (HYSPLIT4) model of the National Oceanographic and Atmospheric Administration and the GDAS1 (Global Data Assimilation System) meteorological data archive (Draxler and Rolph, 2014). To determine if the air mass changed during a sampling period, back trajectories were initiated at the beginning of the sampling period and every $2 \mathrm{~h}$ until the end of the sampling period from a height of $5.5 \mathrm{~m}$. Trajectories were also initiated from heights of 50 and $150 \mathrm{~m}$ a.g.l. for cases where the trajectories approached ground level. The conclusions in this study were not sensitive to the height at which the back trajectories were initiated.

Back trajectories were used to assign each sampling period to one of four general air mass categories: (i) coastal NW, where boundary layer air (defined here as an altitude below $1000 \mathrm{~m}$ ) had traversed land northwest of the sampling site during its approach; (ii) coastal SE, where boundary layer air had traversed land southeast of the sampling site during its approach; (iii) Pacific Ocean, where boundary layer air had approached directly from the ocean and had not encountered land prior to arrival at the sampling site; and (iv) free troposphere, where the air mass had spent more than $50 \%$ of the $72 \mathrm{~h}$ back trajectory in the free troposphere. In four sampling periods, back trajectories initiated at different times in the sampling period indicated that the air mass changed during sampling, for example, as a change in the predominant altitude of the air mass from the free troposphere to the marine boundary layer. In these situations, the air mass category to which the majority of the back trajectories belonged was selected as the air mass category of the sample.

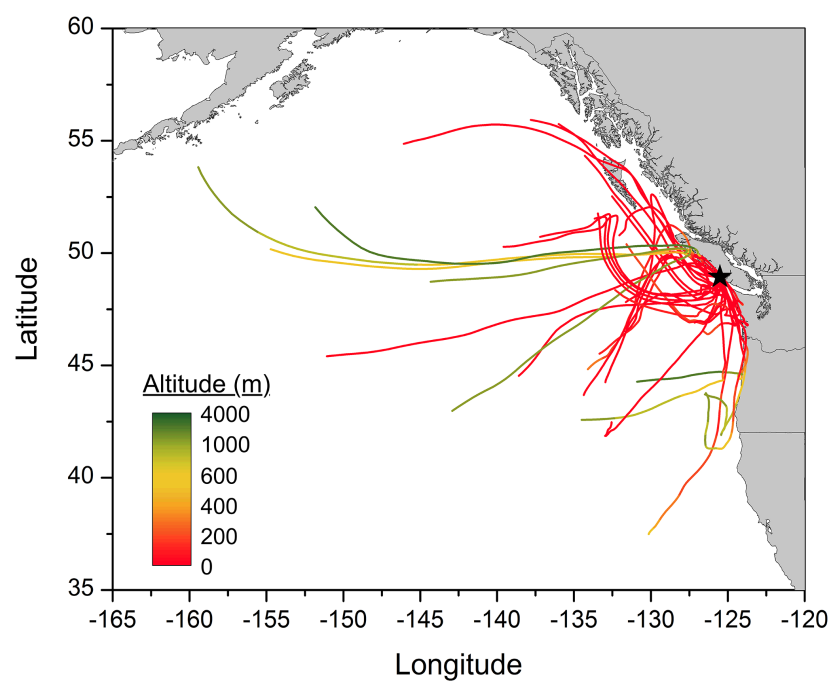

Figure 2. The $72 \mathrm{~h}$ HYSPLIT4 back trajectories of the air masses analyzed at the coastal site (black star) during INP sampling periods. Each back trajectory was initiated from a height of $5.5 \mathrm{~m}$ a.g.l. and at the midpoint of the sampling period.

\section{Results and discussion}

\subsection{Back trajectories and the dependence of INP concentrations on air mass classification}

The $72 \mathrm{~h}$ back trajectories that were initiated at the midpoint of each INP sampling period are shown in Fig. 2. The back trajectories indicate that $88 \%$ of the air masses sampled spent the majority of their $72 \mathrm{~h}$ prior to reaching the site over the Pacific Ocean within the marine boundary layer (est. $<1000 \mathrm{~m}$ ). Furthermore, air masses approached the sampling site from an onshore direction with minimal flow over land apart from coastal regions. Average local wind directions of $89-297^{\circ}$ during INP sampling support this finding. In Fig. S1 in the Supplement, the back trajectories shown in Fig. 2 are color-coded by the classification of the air mass.

Shown in Fig. 3 is the number concentration of INPs as a function of time, color-coded by the classification of the air mass. There is no obvious trend between INP number concentrations and air mass type at temperatures between -15 and $-25^{\circ} \mathrm{C}$. At $-30^{\circ} \mathrm{C}$, INP number concentrations associated with air masses from the coastal SE (red points) appear to be higher than INP number concentrations associated with other air masses, but the statistics are low for the coastal $\mathrm{SE}$ air masses, especially at $-30^{\circ} \mathrm{C}$. Figure 4 shows that the mean values for the different air mass types vary by less than a factor of 2.6. We conclude that INP number concentrations did not exhibit a strong dependence on the type of air mass sampled. The correlation analysis presented in Sects. 3.2-3.5 uses the entire data set (i.e., the data were not differentiated based on air mass type). We further explore the dependence on air mass type in Sect. 3.6. 


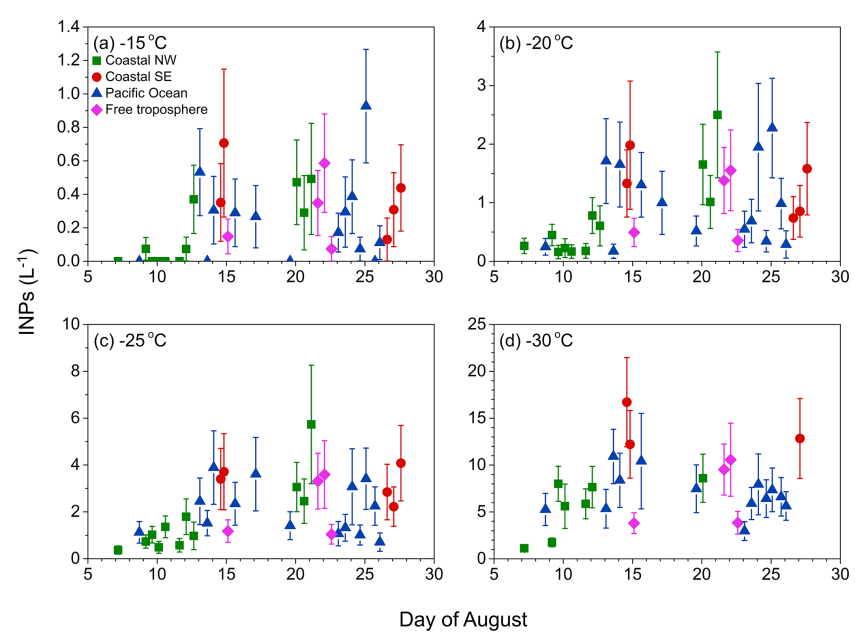

Figure 3. INP number concentrations as a function of date determined at ice-activation temperatures of (a) $-15,(\mathbf{b})-20$, (c) -25 , and (d) $-30^{\circ} \mathrm{C}$. Error bars represent the upper and lower bounds to the INP number concentration as defined by uncertainty in the MOUDI-DFT. The symbols are color-coded by air mass category (see Sect. 2.8 for details). Fewer data points are available at $-30^{\circ} \mathrm{C}$ as INP number concentrations can only be determined to the temperature where all droplets are frozen and Eq. (1) becomes undefined.

\subsection{Are biological particles a major source of ice nuclei?}

To investigate if biological particles are an important source of INPs at the coastal site, we determined correlations between INPs and fluorescent bioparticles. In the following correlation analysis, WIBS-4A data are limited to particle sizes of $0.5-10 \mu \mathrm{m}$ to better match the size range of the MOUDIDFT. The correlation coefficients $(R)$ of linear fits to the data are presented in Table 1 with correlation plots at a freezing temperature of $-25^{\circ} \mathrm{C}$ shown in Fig. 5 and plots at -15 , -20 , and $-30^{\circ} \mathrm{C}$ given in the Supplement. Here we use the scheme of Dancey and Reidy (2011) where correlations with an $R$ value of $0.1-0.3,0.4-0.6$, and $0.7-0.9$ are classified as weak, moderate, and strong, respectively. In the discussion, correlations with statistical significance $(P$ value $<0.05)$ are emphasized.

With values of $R$ between 0.74 and 0.83 , INP number concentrations are strongly correlated with the number concentrations of fluorescent bioparticles for INPs active between -15 and $-25^{\circ} \mathrm{C}$ (Figs. 5a, S3; Table 1). At these temperatures, fluorescent bioparticles have the largest correlation coefficients with INPs compared to all of the other parameters investigated. This suggests that biological particles are an important component of the INP population. Using similar fluorescence techniques, others have also noted strong correlations between INPs and primary biological particles during ambient measurements (Prenni et al., 2009, 2013; Huffman et al., 2013; Tobo et al., 2013).
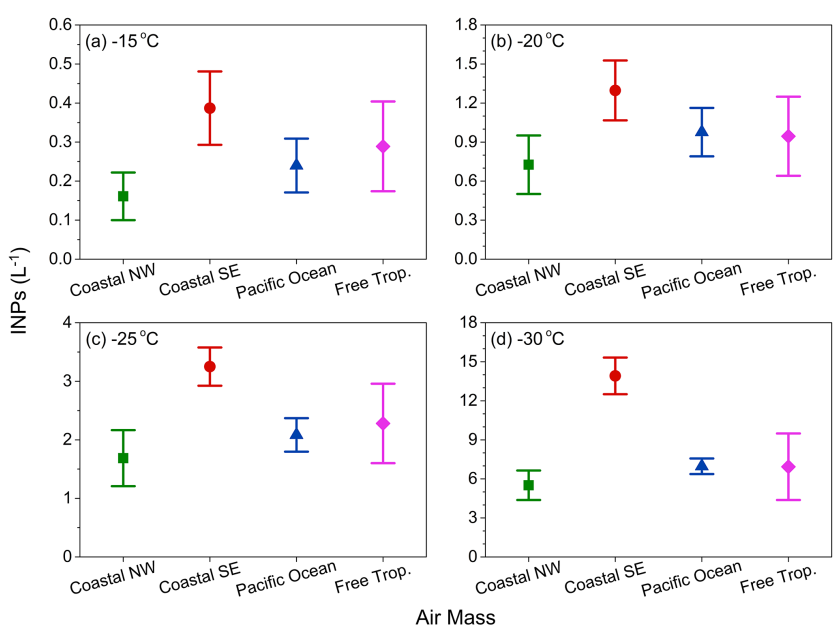

Figure 4. Mean INP number concentrations found in each of the four categories of air masses sampled at (a) -15, (b) -20 , (c) -25 , and (d) $-30^{\circ} \mathrm{C}$. The scheme for air mass classification is given in Sect. 2.8. Uncertainties are given as the standard error of the mean.

To further investigate the relationship between biological particles and INPs, we compared the size distributions of INPs with the size distributions of total particles and fluorescent bioparticles, using samples where all three measurements were available. Shown in Fig. 6a-d are the average number concentrations of INPs as a function of particle size for droplet freezing temperatures ranging from -15 to $-30{ }^{\circ} \mathrm{C}$. The shapes of all four INP size distributions were nearly identical with a single mode at an aerodynamic diameter of 3.2-5.6 $\mu \mathrm{m}$.

Also shown in Fig. 6 are the average size distributions of total particles and fluorescent bioparticles as measured with the WIBS-4A over the size range of $0.5-10 \mu \mathrm{m}$. As mentioned in Sect. 2.3, due to the decrease in WIBS counting efficiency at particle sizes below approximately $0.7 \mu \mathrm{m}$ (Healy et al., 2012b), the number concentration of particles sized $0.5-1.0 \mu \mathrm{m}$ should be considered a lower limit.

The size distribution of total particles (Fig. 6e) was found to be unimodal with the mode at $0.5-1.0 \mu \mathrm{m}$. Fluorescent bioparticles were bimodally distributed (Fig. 6f) with one mode at $1.8-3.2 \mu \mathrm{m}$ and another at $0.5-1.0 \mu \mathrm{m}$. Figure 6 illustrates that the size distributions of INPs are more closely related to the size distribution of fluorescent bioparticles than total particles, suggesting that biological particles may have had a greater contribution to the INP population than nonbiological particles.

In addition to the WIBS-4A, the presence of biological material in sampled air was verified by fluorescence microscopy. Images of a sample collected on 11 August 2013 are shown in Fig. 7 as an example. The fraction of particles exhibiting fluorescence on this day based on the WIBS$4 \mathrm{~A}$ was close to the campaign average value; $7.1 \%$ vs. an average of $7.8 \%$. The image here shows a sample contain- 
Table 1. Correlation coefficients $(R)$ for linear regression analyses of INPs vs. fluorescent bioparticles, total aerosol particles, eBC, sodium, MSA, and wind speed ${ }^{\text {a }}$. Correlations with statistical significance $(P<0.05)$ are shown in bold.

\begin{tabular}{|c|c|c|c|c|c|c|c|c|c|c|c|c|}
\hline \multirow[b]{3}{*}{ Measurement } & \multicolumn{12}{|c|}{ Relation to the INP number concentration } \\
\hline & \multicolumn{3}{|c|}{$-15^{\circ} \mathrm{C}$} & \multicolumn{3}{|c|}{$-20^{\circ} \mathrm{C}$} & \multicolumn{3}{|c|}{$-25^{\circ} \mathrm{C}$} & \multicolumn{3}{|c|}{$-30^{\circ} \mathrm{C}$} \\
\hline & $R$ & $P^{\mathrm{b}}$ & $n^{\mathrm{c}}$ & $R$ & $P$ & $n$ & $R$ & $P$ & $n$ & $R$ & $P$ & $n$ \\
\hline $\begin{array}{l}\text { Fluorescent } \\
\text { bioparticles } \\
{[0.5-10 \mu \mathrm{m}]}\end{array}$ & 0.74 & $<0.01$ & 28 & 0.77 & $<0.01$ & 28 & 0.83 & $<0.01$ & 28 & 0.66 & $<0.01$ & 23 \\
\hline $\begin{array}{l}\text { Total particles } \\
{[0.5-10 \mu \mathrm{m}]}\end{array}$ & 0.33 & 0.04 & 28 & 0.36 & 0.03 & 28 & 0.49 & $<0.01$ & 28 & 0.66 & $<0.01$ & 23 \\
\hline $\mathrm{eBC}$ & 0.47 & $<0.01$ & 34 & 0.59 & $<0.01$ & 34 & 0.60 & $<0.01$ & 34 & 0.25 & 0.11 & 27 \\
\hline Sodium & -0.35 & 0.25 & 6 & 0.13 & 0.40 & 6 & 0.32 & 0.27 & 6 & 0.82 & 0.20 & 3 \\
\hline MSA & 0.17 & 0.38 & 6 & 0.51 & 0.15 & 6 & 0.27 & 0.30 & 6 & 0.00 & 0.50 & 3 \\
\hline $\begin{array}{l}\text { (Wind speed) }^{3.41} \\
\text { Lighthouse }\end{array}$ & 0.05 & 0.39 & 34 & 0.01 & 0.48 & 34 & 0.15 & 0.19 & 34 & 0.48 & $<0.01$ & 27 \\
\hline $\begin{array}{l}(\text { Wind speed })^{3.41} \\
\text { Buoy }\end{array}$ & 0.04 & 0.40 & 34 & 0.04 & 0.40 & 34 & 0.19 & 0.14 & 34 & 0.55 & $<0.01$ & 27 \\
\hline
\end{tabular}

ing many biological particles, identified by their blue color which is characteristic of biological fluorophores such as proteins and coenzymes (Pöhlker et al., 2012). Most of these biological particles exhibited similar morphology with an ellipsoidal shape, approximately $11.9 \mu \mathrm{m}$ in length $\times 4.1 \mu \mathrm{m}$ in width, and transverse septa. Morphologically, many of these appear to be fungal macroconidia, consistent with the physical attributes of ascospores (Carlile et al., 2001; Maheshwari, 2005; Leslie and Summerell, 2006; Webster and Weber, 2007). Fungal spores can be ice-active at the temperatures used here (Jayaweera and Flanagan, 1982; Pouleur et al., 1992; Tsumuki et al., 1992; Richard et al., 1996; Iannone et al., 2011; Haga et al., 2013, 2014; Fröhlich-Nowoisky et al., 2015), and the size of the bioparticles observed in Fig. 7 (an estimated aerodynamic diameter of $4.8 \mu \mathrm{m}$ assuming a prolate spheroid shape and unit density) matches the mode in the INP size distributions of Fig. 6. Predicting the optical diameter that the WIBS-4A would measure for such a particle is difficult, but it is reasonable that they could be detected as slightly larger or smaller depending on the axis upon which the incident light impinges.

\subsection{Is black carbon a major source of ice nuclei?}

Sources of BC at the sampling site include local marine ship traffic. Atmospheric size distributions obtained at other locations demonstrate that most $\mathrm{BC}$ particles are smaller than $1 \mu \mathrm{m}$ (Schwarz et al., 2008, 2013; Schroder et al., 2015). As is shown in Fig. 6, the majority of INPs identified here were larger than $1 \mu \mathrm{m}$ at all of the temperatures studied. It is therefore likely that BC particles were not a major source of INPs at the sampling site. As correlations between INPs and eBC are moderate at -15 to $-25^{\circ} \mathrm{C}(R=0.47-0.60$, Table 1$)$, we also investigated correlations between INPs and the anthropogenic tracers $\mathrm{CO}, \mathrm{NO}_{x}$, and $\mathrm{SO}_{2}$. The correlations between INPs and $\mathrm{CO}, \mathrm{NO}_{x}$, and $\mathrm{SO}_{2}$ are not statistically significant (see Table S2), further suggesting that $\mathrm{BC}$ was not a major INP source.

\subsection{Are particles from the ocean a major source of ice nuclei?}

Situated in a region of high oceanic primary productivity (Whitney et al., 2005; Ribalet et al., 2010) with onshore winds, particles of marine origin are a potential source of INPs at the sampling site. Therefore, correlations between INP number concentrations and tracers of marine aerosols and marine biological activity were explored. Since primary marine aerosols are ejected from the ocean by the bursting of entrained bubbles (Blanchard and Woodcock, 1957; Blanchard, 1963, 1989; Andreas, 1998), sodium was used as a tracer of primary particles from the ocean. The strength of correlations between INPs and sodium are given in Table 1. Although the correlations range from weakly-to-moderately negative to strongly positive, the large $P$ values $(0.20$ or greater) indicate that the results are not statistically significant. Due in part to the long sampling times required for 

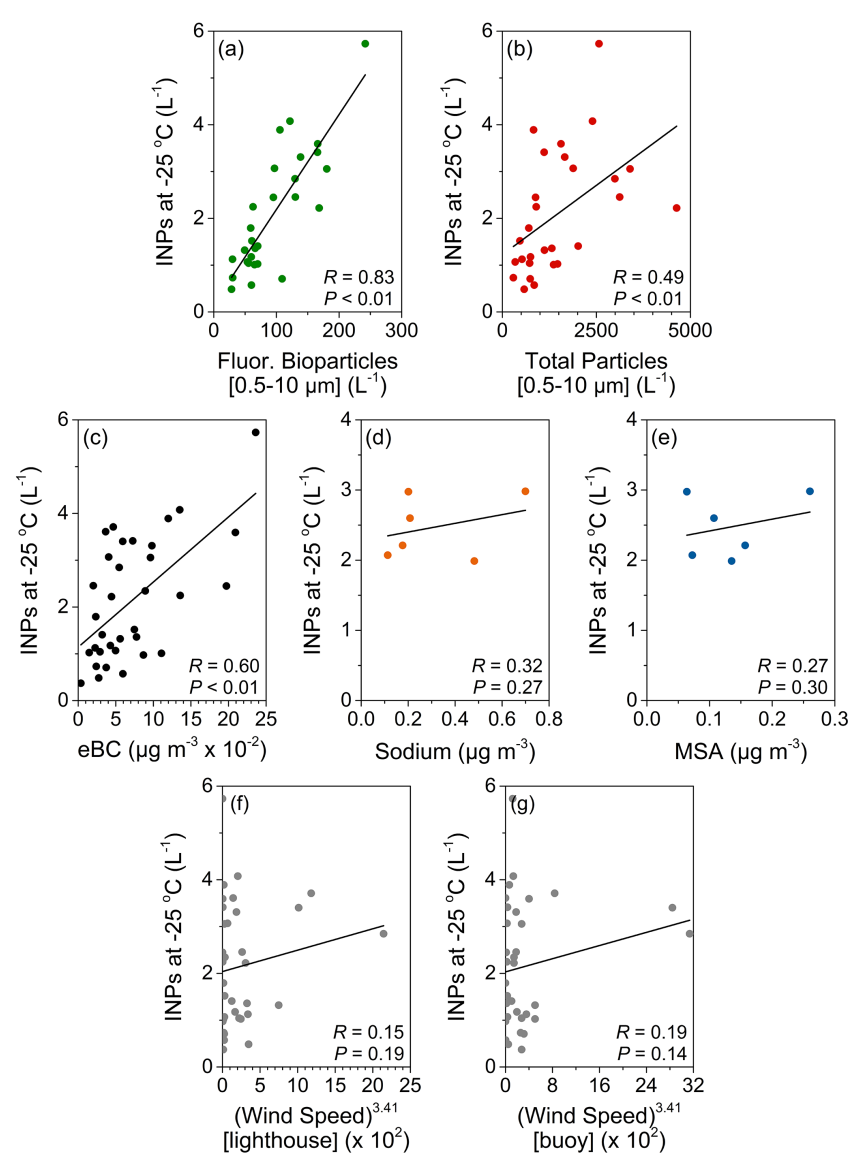

Figure 5. Number concentrations of INPs active at $-25^{\circ} \mathrm{C}$ plotted against concentrations of (a) fluorescent bioparticles of $0.5-10 \mu \mathrm{m}$, (b) total particles of $0.5-10 \mu \mathrm{m}$, (c) eBC, (d) sodium, (e) MSA, and (f, g) (wind speed) ${ }^{3.41}$ based on the power law function of Monahan and Muircheartaigh (1980) where wind speed was in units of meters per second. Linear fits are shown with corresponding correlation coefficients $(R)$ and probability values $(P)$.

the sodium measurements, only three to six data points were available for the sodium correlation analysis.

MSA is often used as a marker for marine biological productivity (Saltzman et al., 1986; Savoie et al., 1994; Sorooshian et al., 2009; Gaston et al., 2010; Becagli et al., 2013) because it is chemically stable and its precursor, dimethyl sulfide, is produced by primary biological activity in the ocean (Andreae et al., 1985; Charlson et al., 1987; Keller, 1989; Bates et al., 1992; Kettle et al., 1999). As INP number concentrations are closely correlated to bioparticles at warmer droplet freezing temperatures, one may expect correlations of a similar magnitude between INPs and MSA if the marine environment was indeed acting as an important source of biological INPs. As is shown in Table 1, no statistically significant correlations are found as $P$ values are large (0.15-0.50).

Finally, correlations between wind speed and INP number concentration were investigated using wind speed data
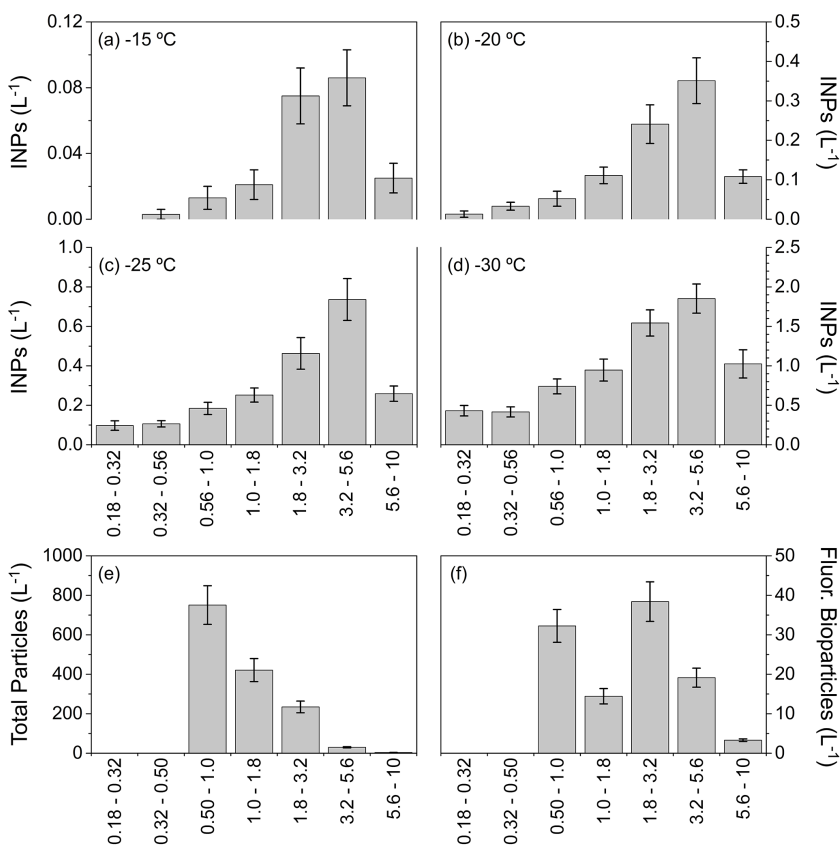

Particle Diameter $(\mu \mathrm{m})$

Figure 6. Mean number concentrations as a function of size for INPs active at (a) -15 , (b) -20 , (c) -25 , and (d) $-30^{\circ} \mathrm{C}$, and total particles between 0.5 and $10 \mu \mathrm{m}$ (e) and fluorescent bioparticles between 0.5 and $10 \mu \mathrm{m}$ (f). Here we use only samples where both the MOUDI-DFT and WIBS-4A were operating. Uncertainties are given as the standard error of the mean. As INP number concentrations can only be determined at temperatures lower than the temperature where all droplets are frozen and Eq. (1) becomes undefined, fewer samples are represented at $-30^{\circ} \mathrm{C}$. Number concentrations below $0.5 \mu \mathrm{m}$ were not measured by the WIBS-4A for panels (e) and (f) but plot axes are consistent for easier comparison of the size distributions.

from both the site and an offshore buoy. As the dominant source of bubble entrainment in the oceans is breaking waves (O'Dowd and de Leeuw, 2007), the rate of sea-spray production is dependent in part on wind speed. For this correlation, wind speed was first raised to the power of 3.41 using the power law of Monahan and Muircheartaigh (1980) that relates whitecap coverage to wind speed. The correlations found at $-30^{\circ} \mathrm{C}$ are statistically significant $(P$ value $<0.05)$, but the magnitude of the correlation coefficients is only moderate $(R=0.48-0.55$; see Table 1$)$. The average wind speed during INP sampling exceeded the onset speed for whitecap formation, approximately $4 \mathrm{~m} \mathrm{~s}^{-1}$ (O'Dowd and de Leeuw, 2007 ), in only 47 and $56 \%$ of samples when using the lighthouse and buoy data, respectively, and daily observations at the site noted infrequent wave activity. Furthermore, some of the highest INP concentrations were found when the wind speed was less than $4 \mathrm{~m} \mathrm{~s}^{-1}$. The correlation between local wind direction and INP concentrations was also weak $(R$ ranged from -0.19 to -0.32 ; not shown). 
(a)

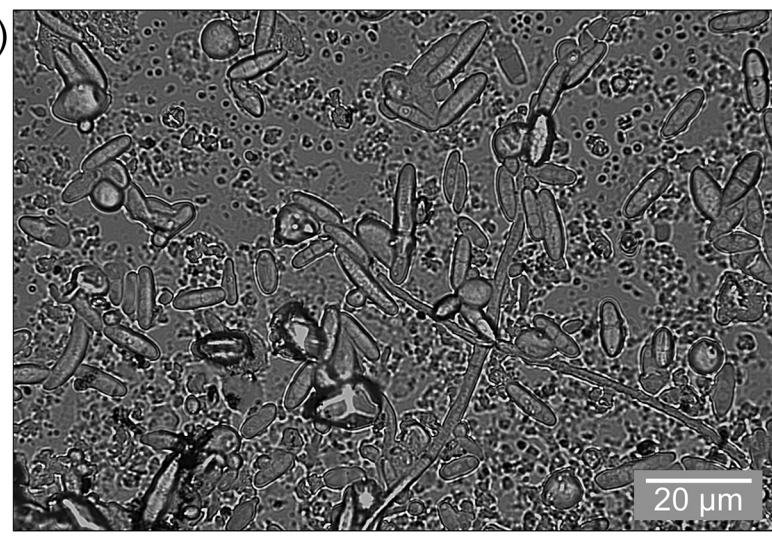

(b)

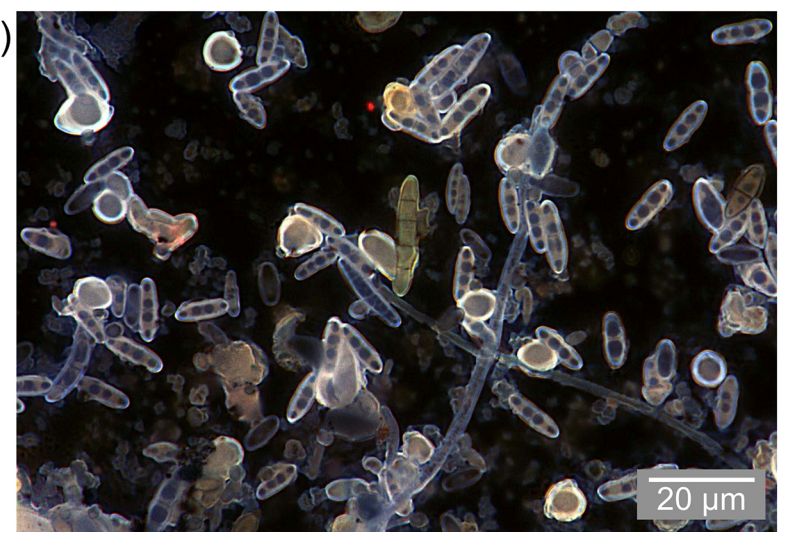

Figure 7. Fluorescence microscopy images of an aerosol sample collected on 11 August 2013: (a) bright-field image, (b) an overlay of red, green, and blue fluorescence channels. A blue coloration is characteristic of biological material (Pöhlker et al., 2012).

All correlations between INPs and parameters indicative of marine aerosols and marine biological activity are either moderate at best or not statistically significant. For these reasons, correlations involving sodium, MSA, and wind speed do not provide strong evidence that marine particles were a major contributor to the INP population. Recent measurements have shown the presence of INPs in the sea surface microlayer (Wilson et al., 2015). Our measurements do not contradict these findings since we do not rule out the ocean as a source of INPs. One possibility is that biological INPs released by local vegetation were present in sufficient numbers to overwhelm the presence of any INPs from the ocean.

\subsection{What is the major source of ice nuclei active at $-30{ }^{\circ} \mathrm{C}$ ?}

At warmer droplet freezing temperatures $\left(-15\right.$ to $\left.-25^{\circ} \mathrm{C}\right)$, the strongest correlations are observed between number concentrations of fluorescent bioparticles and INPs. In contrast, at $-30^{\circ} \mathrm{C}$ the strength of correlations between INPs and fluorescent bioparticles and INPs and total particles $>0.5 \mu \mathrm{m}$ in diameter are equal $(R=0.66$; Table 1$)$. It is therefore likely that both biological and non-biological particles were impor- tant sources of INPs active at $-30^{\circ} \mathrm{C}$. Good correlations between INPs and total particles $>0.5 \mu \mathrm{m}$ have also been observed in several other field studies (e.g., DeMott et al., 2010; Chou et al., 2011; Field et al., 2012; Prenni et al., 2013; Tobo et al., 2013; Jiang et al., 2015).

Since the INP size distributions of Fig. 6 and the correlations of Table 1 do not provide strong evidence of BC particles or the ocean being a major source of INPs active at $-30^{\circ} \mathrm{C}$, it is possible that mineral dust was a major source of INPs as mineral dust particles are known to efficiently nucleate ice at this temperature (e.g., DeMott et al., 2003; Cziczo et al., 2004; Field et al., 2006; Möhler et al., 2006; Marcolli et al., 2007; Zimmermann et al., 2008; Klein et al., 2010; Niedermeier et al., 2010; Chou et al., 2011; Atkinson et al., 2013; Yakobi-Hancock et al., 2013; Wheeler et al., 2015). The size distribution of INPs did not drastically change between -25 and $-30^{\circ} \mathrm{C}$ (Fig. $6 \mathrm{c}, \mathrm{d}$ ), and the dominant mode in the surface area distribution of airborne mineral dust (Maring et al., 2003) can occur at approximately the same size range as biological INPs (Després et al., 2012). While in a very different ecosystem and climatic region, Prenni et al. (2009) noted that the relative contribution of mineral dust particles to the total number of INPs in the Amazon region increased as ice nucleation temperature decreased. Only below $-27^{\circ} \mathrm{C}$ did the amount of mineral dust significantly influence the number of INPs, while above this temperature most INPs were biological (Prenni et al., 2009). The 10-day back trajectories initiated at the midpoint of each INP sampling period are available in Fig. S2. None of the trajectories pass over major arid regions in Asia or Africa; however, this does not rule out mineral dust or soils as a source of INPs in our measurements.

\subsection{Do the potential sources of ice nuclei change with air mass classification?}

In the preceding sections we did not differentiate data based on air mass classification. Here we present correlations within each of the four air mass categories introduced in Sect. 2.8 to investigate if the major sources of INPs vary with air mass type. The correlations for each air mass type are given in Table 2. Correlations involving sodium and MSA are not included due to insufficient data, and only statistically significant correlations will be discussed $(P<0.05)$.

The general trends presented in Table 1 for the undifferentiated data are also found in Table 2 for the various air mass categories. In coastal NW, Pacific Ocean, and free tropospheric air masses, INP number concentrations are well correlated to those of fluorescent bioparticles at temperatures between -15 and $-25^{\circ} \mathrm{C}$ with $R$ values ranging from 0.64 to 0.99 (an average of 0.89 ), and in free tropospheric air masses a very strong correlation is also found at $-30^{\circ} \mathrm{C}(R=1.00)$. In most cases, these are the strongest correlations noted at a given temperature. This again suggests that many INPs may have been biological. 
Table 2. Correlation coefficients $(R)$ for linear regression analyses of INPs vs. fluorescent bioparticles, total aerosol particles, eBC, and wind speed $^{\mathrm{a}}$ within each category of air mass. Correlations with statistical significance $(P<0.05)$ are shown in bold.

\begin{tabular}{|c|c|c|c|c|c|c|c|c|c|c|c|c|c|}
\hline \multirow[b]{3}{*}{ Air Mass } & \multirow[b]{3}{*}{ Measurement } & \multicolumn{12}{|c|}{ Relation to the INP number concentration } \\
\hline & & \multicolumn{3}{|c|}{$-15^{\circ} \mathrm{C}$} & \multicolumn{3}{|c|}{$-20^{\circ} \mathrm{C}$} & \multicolumn{3}{|c|}{$-25^{\circ} \mathrm{C}$} & \multicolumn{3}{|c|}{$-30^{\circ} \mathrm{C}$} \\
\hline & & $R$ & $P^{\mathrm{b}}$ & $n^{\mathrm{c}}$ & $R$ & $P$ & $n$ & $R$ & $P$ & $n$ & $R$ & $P$ & $n$ \\
\hline \multirow[t]{5}{*}{ Coastal NW } & $\begin{array}{l}\text { Fluorescent } \\
\text { bioparticles } \\
{[0.5-10 \mu \mathrm{m}]}\end{array}$ & 0.94 & $<0.01$ & 9 & 0.94 & $<0.01$ & 9 & 0.96 & $<0.01$ & 9 & 0.65 & 0.08 & 6 \\
\hline & $\begin{array}{l}\text { Total particles } \\
{[0.5-10 \mu \mathrm{m}]}\end{array}$ & 0.85 & $<0.01$ & 9 & 0.70 & 0.02 & 9 & 0.71 & 0.02 & 9 & 0.67 & 0.07 & 6 \\
\hline & $\mathrm{eBC}$ & 0.71 & $<0.01$ & 11 & 0.80 & $<0.01$ & 11 & 0.84 & $<0.01$ & 11 & 0.53 & 0.11 & 7 \\
\hline & 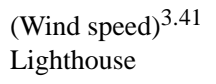 & -0.38 & 0.12 & 11 & -0.39 & 0.12 & 11 & -0.22 & 0.26 & 11 & 0.26 & 0.29 & 7 \\
\hline & $\begin{array}{l}\text { (Wind speed })^{3.41} \\
\text { Buoy }\end{array}$ & -0.03 & 0.47 & 11 & 0.00 & 0.49 & 11 & 0.00 & 0.50 & 11 & -0.02 & 0.48 & 7 \\
\hline \multirow[t]{5}{*}{ Coastal SE } & $\begin{array}{l}\text { Fluorescent } \\
\text { bioparticles } \\
{[0.5-10 \mu \mathrm{m}]}\end{array}$ & -0.07 & 0.48 & 3 & -0.53 & 0.32 & 3 & -0.85 & 0.17 & 3 & $\mathrm{NA}^{d}$ & & \\
\hline & $\begin{array}{l}\text { Total particles } \\
{[0.5-10 \mu \mathrm{m}]}\end{array}$ & -0.17 & 0.45 & 3 & -0.61 & 0.29 & 3 & -0.90 & 0.14 & 3 & NA & & \\
\hline & $\mathrm{eBC}$ & 0.07 & 0.46 & 5 & 0.28 & 0.32 & 5 & 0.67 & 0.11 & 5 & 0.96 & 0.09 & 3 \\
\hline & $\begin{array}{l}\text { (Wind speed }^{3.41} \\
\text { Lighthouse }\end{array}$ & -40.34 & 0.29 & 5 & -0.27 & 0.33 & 5 & -0.14 & 0.41 & 5 & 0.21 & 0.43 & 3 \\
\hline & 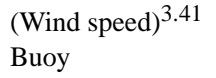 & -0.52 & 0.18 & 5 & -0.37 & 0.27 & 5 & -0.12 & 0.43 & 5 & 0.93 & 0.12 & 3 \\
\hline \multirow[t]{5}{*}{ Pacific Ocean } & $\begin{array}{l}\text { Fluorescent } \\
\text { bioparticles } \\
{[0.5-10 \mu \mathrm{m}]}\end{array}$ & 0.80 & $<0.01$ & 12 & 0.74 & $<0.01$ & 12 & 0.64 & 0.01 & 12 & 0.23 & 0.24 & 12 \\
\hline & $\begin{array}{l}\text { Total particles } \\
{[0.5-10 \mu \mathrm{m}]}\end{array}$ & 0.13 & 0.34 & 12 & 0.30 & 0.17 & 12 & 0.21 & 0.25 & 12 & 0.25 & 0.22 & 12 \\
\hline & $\mathrm{eBC}$ & 0.24 & 0.21 & 14 & 0.37 & 0.10 & 14 & 0.26 & 0.19 & 14 & 0.06 & 0.42 & 13 \\
\hline & 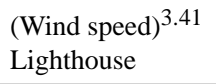 & -0.10 & 0.37 & 14 & -0.26 & 0.18 & 14 & -0.26 & 0.19 & 14 & -0.21 & 0.25 & 13 \\
\hline & $\begin{array}{l}\text { (Wind speed })^{3.41} \\
\text { Buoy }\end{array}$ & -0.18 & 0.27 & 14 & -0.38 & 0.09 & 14 & -0.48 & 0.04 & 14 & -0.22 & 0.23 & 13 \\
\hline \multirow[t]{5}{*}{ Free troposphere } & $\begin{array}{l}\text { Fluorescent } \\
\text { bioparticles } \\
{[0.5-10 \mu \mathrm{m}]}\end{array}$ & 0.97 & 0.02 & 4 & 0.99 & $<0.01$ & 4 & 0.99 & $<0.01$ & 4 & 1.00 & $<0.01$ & 4 \\
\hline & $\begin{array}{l}\text { Total particles } \\
{[0.5-10 \mu \mathrm{m}]}\end{array}$ & 0.86 & 0.07 & 4 & 0.98 & 0.01 & 4 & 0.99 & $<0.01$ & 4 & 0.98 & 0.01 & 4 \\
\hline & $\mathrm{eBC}$ & 0.99 & $<0.01$ & 4 & 0.89 & 0.05 & 4 & 0.88 & 0.06 & 4 & 0.89 & 0.06 & 4 \\
\hline & $\begin{array}{l}\text { (Wind speed) }^{3.41} \\
\text { Lighthouse }\end{array}$ & -0.89 & 0.05 & 4 & -0.70 & 0.15 & 4 & -0.67 & 0.17 & 4 & -0.68 & 0.16 & 4 \\
\hline & $\begin{array}{l}\text { (Wind speed) })^{3.41} \\
\text { Buoy }\end{array}$ & 0.62 & 0.19 & 4 & 0.39 & 0.31 & 4 & 0.38 & 0.31 & 4 & 0.42 & 0.29 & 4 \\
\hline
\end{tabular}


In coastal NW and free tropospheric air masses, INPs and total particles are also closely correlated. These correlations are strong in the case of coastal NW air masses at ice activation temperatures of -15 to $-25^{\circ} \mathrm{C}(R=0.70-0.85)$ and very strong in air masses from the free troposphere between -20 and $-30^{\circ} \mathrm{C}(R=0.98-0.99)$. The correlation coefficients are significantly greater than those found in the undifferentiated data of Table 1 . With the average fraction of particles that exhibited fluorescence in these air masses being close to the campaign average, the good correlations with total particles suggest that non-biological INPs such as mineral dust may have also contributed to the INP population.

Correlations of INPs with eBC are strong $(R=0.71-0.84)$ at $-25^{\circ} \mathrm{C}$ and above in coastal NW air masses and very strong $(R=0.99)$ at $-15^{\circ} \mathrm{C}$ in air masses from the free troposphere. Correlations of INPs with $\mathrm{CO}$ and $\mathrm{SO}_{2}$ in these air masses are also moderate to very strong in some cases (see Table S3). However, more than 84 and $100 \%$ of INPs active at these temperatures were larger than $1 \mu \mathrm{m}$ in size in air masses from the coastal NW and the free troposphere, respectively. Vegetation NW of the sampling site closely follows that of the region, and potential sources of supermicron INPs from the coastal NW include forests of coastal western hemlock. Given the dominance of supermicron INPs in these two air mass types, it is unlikely that $\mathrm{BC}$ was an important source of INPs.

\subsection{Can existing parameterizations accurately predict measured INP concentrations?}

Empirical parameterizations have been developed to predict ice nucleation in atmospheric models. Here we investigate whether or not a number of these parameterizations are consistent with the current measurements. In total we tested six different parameterizations: those of Fletcher (1962), hereafter F62; Cooper (1986), hereafter C86; Meyers et al. (1992), hereafter M92; DeMott et al. (2010), hereafter D10; and two from Tobo et al. (2013), hereafter T13 total and $\mathrm{T} 13_{\text {fluorescent. }}$. Details on these parameterizations are given in the Supplement.

In Fig. 8 we compare measured INP number concentrations with predicted INP number concentrations based on the parameterizations discussed above. The parameterizations of D10, $\mathrm{T} 13_{\text {total }}$, and $\mathrm{T} 13_{\text {fluorescent }}$ require knowledge of either total particle or fluorescent bioparticle number concentrations with sizes $>0.5 \mu \mathrm{m}$. Here we use the data from the WIBS-4A over its full size range $(0.5-23.7 \mu \mathrm{m})$ to better match the sampling conditions used in D10 and T13. Note that the parameterization of $\mathrm{T} 13$ fluorescent based on fluorescent bioparticle number concentrations was formulated using measurements from an ultraviolet aerodynamic particle sizer (UV-APS), whereas this study uses a WIBS-4A. As noted in Healy et al. (2014), there may be discrepancies between the number concentrations of fluorescent bioparticles detected by the UV-APS and WIBS-4A. With more fluores-
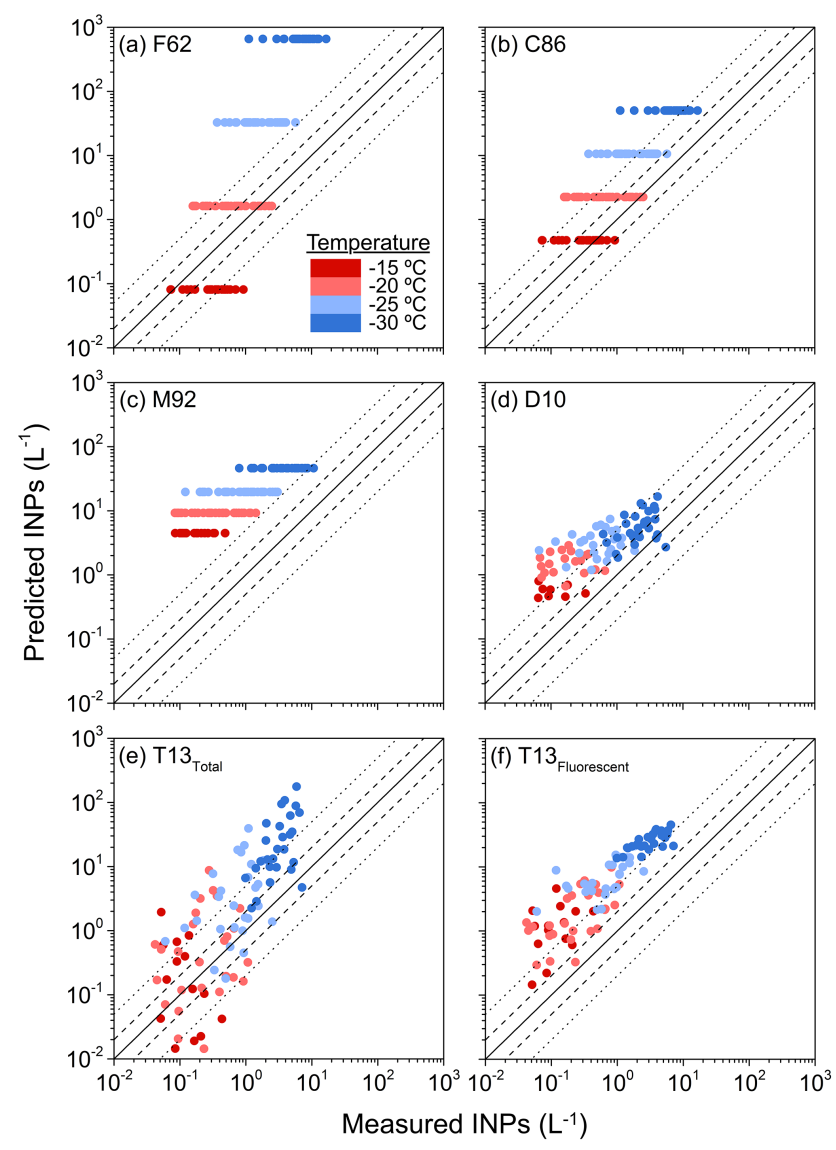

Figure 8. Predicted vs. measured INP number concentrations based on the parameterizations of (a) Fletcher (1962), (b) Cooper (1986), (c) Meyers et al. (1992), (d) DeMott et al. (2010), and (e, f) Tobo et al. (2013). Details on these parameterizations are given in the Supplement. Data color represents ice nucleation temperatures. This figure uses the format of Fig. 9 in Tobo et al. (2013).

cent channels and more sensitive electronics, the WIBS-4A may probe different fluorophores than the UV-APS, thus detecting greater concentrations of fluorescent bioparticles and in turn leading to greater predicted INP number concentrations. Also, the INP number concentrations measured by the MOUDI-DFT are for particle sizes of 0.18-10 $\mu \mathrm{m}$, whereas the INP measurements used to formulate the parameterizations of M92, D10, and T13 were for particles $\leq 3, \leq 1.6$, and $\leq 2.4 \mu \mathrm{m}$, respectively. As a result, when reporting measured INP number concentrations in Fig. 8 we limit the MOUDIDFT data to particle sizes that overlap with those used to formulate the parameterizations (see the Supplement for details).

It is evident in Fig. 8 that none of the parameterizations are able to consistently predict the measured INP number concentrations within a factor of 5 over the entire temperature range investigated. The most accurate parameterization is that of C86 (Fig. 8b), predicting 25 and $57 \%$ of the INP number concentrations within a factor of 2 and 5 , respec- 
tively, of the solid $1: 1$ line. While the $\mathrm{C} 86$ parameterization works reasonably well at temperatures of -15 to $-25^{\circ} \mathrm{C}$, at lower temperatures it becomes increasingly inaccurate, possibly due to it being applied outside the temperature range over which it was developed $\left(-5\right.$ to $\left.-25^{\circ} \mathrm{C}\right)$.

The parameterizations of $\mathrm{D} 10, \mathrm{~T} 13_{\text {total }}$, and $\mathrm{T} 13_{\text {fluorescent }}$ incorporate measurements of total particles or fluorescent bioparticles but are found to be poor predictors of the values measured in this study as on average only $41 \%$ of INP number concentrations are predicted within a factor of 5 (Fig. 8df). A number of data sets from diverse locations were used in the development of the D10 parameterization, but those with a strong marine influence were not included because sea salt is not known to be an efficient ice nucleus under the conditions investigated (immersion freezing at temperatures above $-35^{\circ} \mathrm{C}$ ). Given the proximity of our sampling site to the Pacific Ocean (Fig. 1) and the back trajectories of the sampled air masses (Fig. 2), a marine influence in our samples may contribute to the somewhat poor performance of the D10 parameterization and the overestimation of INPs shown in Fig. 8d. The T13 $3_{\text {total }}$ and T13 1 fluorescent parameterizations were developed using data from a forested site in Colorado. Differences in the composition, concentration, and ice-nucleating ability of both biological and nonbiological particles between the continental forest of T13 and the coastal site of this study may have contributed to the inaccuracy of the $\mathrm{T} 13_{\text {total }}$ and $\mathrm{T} 13_{\text {fluorescent }}$ parameterizations (Fig. 8e, f).

Figure 8 suggests that additional measurements of INPs in other environments, times of year, and altitudes are needed to further test and improve current empirical parameterizations of INPs. The results presented in Fig. 8 also indicate that the application of INP parameterizations to locations dissimilar to that of the original study used to generate the parameterizations should be done with care.

\section{Summary and conclusions}

The number concentrations of $0.18-10 \mu \mathrm{m}$ INPs active in the immersion mode were determined at a coastal site in western Canada during the summer of 2013 as part of the NETCARE project. We investigated the strength of linear correlations between these INP values and measurements of total particles, fluorescent bioparticles, eBC, sodium, MSA, and wind speed and also compared their size distributions where these measurements were available. We found that (1) biological particles, possibly from local vegetation, were likely the major source of ice nuclei at freezing temperatures between -15 and $-25^{\circ} \mathrm{C}$; (2) non-biological particles such as mineral dust may also have had an important contribution to the population of INPs active at $-30^{\circ} \mathrm{C}$; (3) the prevalence of supermicron INPs makes BC particles an unlikely source of ice nuclei; and (4) there was no evidence of marine particles being a significant source of ice nuclei, although the ocean as a source of INPs cannot be ruled out. One possibility is that biological INPs released by nearby vegetation were present in sufficient numbers at this site to overwhelm the presence of any INPs from the ocean.

Six empirical parameterizations of ice nucleation for use in atmospheric models were tested to determine the accuracy with which they predict INP number concentrations at this coastal site. Overall, none of the parameterizations were found to be suitable, predicting only $1-57 \%$ of INPs within a factor of 5 of the measured value. This highlights the need for the development of INP parameterizations that are appropriate for this complex environment.

In this paper we assumed that particles were externally mixed. In future studies it would be useful to include mixing state measurements together with studies similar to those presented here to quantify the extent of external vs. internal mixing. In addition, studies that identify INPs followed by chemical composition measurements of these particles by electron microscopy (e.g., Knopf et al., 2014) or fluorescence microscopy would be useful to supplement the information gained from correlation analyses of collocated instruments.

\section{The Supplement related to this article is available online at doi:10.5194/acp-15-12547-2015-supplement.}

Acknowledgements. The authors thank K. Bach, O. Greiner, J. Hansen, A. Klady, K. Love, D. Lovrity, T. Mittertreiner, R. Neagu, and P. Padhiar for designing and constructing the NETCARE mobile laboratory used in this study, A. Chivulescu for assistance with ion chromatography measurements, D. O'Connor for assistance analyzing and interpreting WIBS-4A measurements, and L. A. Miller for helpful discussions. The sampling site at Amphitrite Point is located at a Coast Guard station and we would like to thank the Department of Fisheries and Oceans and all the staff at the site for their help. The site is jointly supported and maintained by Environment Canada, the British Columbia Ministry of Environment, and Metro Vancouver. The Natural Sciences and Engineering Research Council of Canada supported this research through its Climate Change and Atmospheric Research program. The authors gratefully acknowledge the NOAA Air Resources Laboratory (ARL) for the provision of the HYSPLIT transport and dispersion model and READY website (http://www.ready.noaa.gov) used in this publication. J. A. Huffman and J. Li acknowledge internal faculty support from the Division of Natural Sciences and Math and PROF grant support from the Office of Research and Sponsored Programs at the University of Denver.

Edited by: R. Sullivan

\section{References}

Alpert, P. A., Aller, J. Y., and Knopf, D. A.: Ice nucleation from aqueous $\mathrm{NaCl}$ droplets with and without marine diatoms, At- 
mos. Chem. Phys., 11, 5539-5555, doi:10.5194/acp-11-55392011, 2011.

Andreae, M. O., Ferek, R. J., Bermond, F., Byrd, K. P., Engstrom, R. T., Hardin, S., Houmere, P. D., LeMarrec, F., Raemdonck, H., and Chatfield, R. B.: Dimethyl sulfide in the marine atmosphere, J. Geophys. Res., 90, 12891-12900, doi:10.1029/JD090iD07p12891, 1985.

Andreas, E. L.: A New Sea Spray Generation Function for Wind Speeds up to $32 \mathrm{~m} \mathrm{~s}^{-1}$, J. Phys. Oceanogr., 28, 2175-2184, 1998.

Atkinson, J. D., Murray, B. J., Woodhouse, M. T., Whale, T. F., Baustian, K. J., Carslaw, K. S., Dobbie, S., O'Sullivan, D., and Malkin, T. L.: The importance of feldspar for ice nucleation by mineral dust in mixed-phase clouds, Nature, 498, 355-358, doi:10.1038/nature12278, 2013.

Augustin, S., Wex, H., Niedermeier, D., Pummer, B., Grothe, H., Hartmann, S., Tomsche, L., Clauss, T., Voigtländer, J., Ignatius, K., and Stratmann, F.: Immersion freezing of birch pollen washing water, Atmos. Chem. Phys., 13, 10989-11003, doi:10.5194/acp-13-10989-2013, 2013.

Austin, M. A., Buffet, D. A., Nicholson, D. J., and Scudder, G. G. E.: Taking Natures Pulse: The Status of Biodiversity in British Columbia, Biodiversity BC, Victoria, available at: http://www. biodiversitybc.org (last access: 10 October 2014), 2008.

Baker, M. B.: Cloud Microphysics and Climate, Science, 276, 1072-1078, doi:10.1126/science.276.5315.1072, 1997.

Bates, T. S., Calhoun, J. A., and Quinn, P. K.: Variations in the methanesulfonate to sulfate molar ratio in submicrometer marine aerosol particles over the South Pacific Ocean, J. Geophys. Res.-Oceans, 97, 9859-9865, doi:10.1029/92JD00411, 1992.

Becagli, S., Lazzara, L., Fani, F., Marchese, C., Traversi, R., Severi, M., di Sarra, A., Sferlazzo, D., Piacentino, S., Bommarito, C., Dayan, U., and Udisti, R.: Relationship between methanesulfonate $\left(\mathrm{MS}^{-}\right)$in atmospheric particulate and remotely sensed phytoplankton activity in oligo-mesotrophic central Mediterranean Sea, Atmos. Environ., 79, 681-688, doi:10.1016/j.atmosenv.2013.07.032, 2013.

Blanchard, D. C.: The electrification of the atmosphere by particles from bubbles in the sea, Prog. Oceanogr., 1, 73-202, doi:10.1016/0079-6611(63)90004-1, 1963.

Blanchard, D. C.: The ejection of drops from the sea and their enrichment with bacteria and other materials: A review, Estuaries, 12, 127-137, doi:10.2307/1351816, 1989.

Blanchard, D. C. and Woodcock, A. H.: Bubble formation and modification in the sea and its meteorological significance, Tellus, 9, 145-158, doi:10.1111/j.2153-3490.1957.tb01867.x, 1957.

Bones, D. L., Henricksen, D. K., Mang, S. A., Gonsior, M., Bateman, A. P., Nguyen, T. B., Cooper, W. J., and Nizkorodov, S. A.: Appearance of strong absorbers and fluorophores in limonene$\mathrm{O}_{3}$ secondary organic aerosol due to $\mathrm{NH}_{4}^{+}$-mediated chemical aging over long time scales, J. Geophys. Res., 115, D05203, doi:10.1029/2009JD012864, 2010.

Boucher, O., Randall, D., Artaxo, P., Bretherton, C., Feingold, G., Foster, P., Kerminen, V.-M., Kondo, Y., Liao, H., Lohmann, U., Rasch, P., Satheesh, S. K., Sherwood, S., Stevens, B. and Boucher, O., Randall, D., Artaxo, P., Bretherton, C., Feingold, G., Foster, P., Kerminen, V.-M., Kondo, Y., Liao, H., Lohmann, U., Rasch, P., Satheesh, S. K., Sherwood, S., Stevens, B., and Zhang, X. Y.: Clouds and Aerosols, in Climate Change 2013: The Physical Science Basis. Contribution of Working Group I to the Fifth Assessment Report of the Intergovernmental Panel on Climate Change, edited by: Stocker, T. F., Qin, D., Plattner, G.K., Tignor, M., Allen, S. K., Boschung, J., Nauels, A., Xia, Y., Bex, V., and Midgley, P. M., Cambridge University Press, Cambridge, United Kingdom and New York, NY, USA, 2013.

Broadley, S. L., Murray, B. J., Herbert, R. J., Atkinson, J. D., Dobbie, S., Malkin, T. L., Condliffe, E., and Neve, L.: Immersion mode heterogeneous ice nucleation by an illite rich powder representative of atmospheric mineral dust, Atmos. Chem. Phys., 12, 287-307, doi:10.5194/acp-12-287-2012, 2012.

Brooks, S. D., Suter, K., and Olivarez, L.: Effects of Chemical Aging on the Ice Nucleation Activity of Soot and Polycyclic Aromatic Hydrocarbon Aerosols, J. Phys. Chem. A, 118, 1003610047, doi:10.1021/jp508809y, 2014.

Burrows, S. M., Hoose, C., Pöschl, U., and Lawrence, M. G.: Ice nuclei in marine air: biogenic particles or dust?, Atmos. Chem. Phys., 13, 245-267, doi:10.5194/acp-13-245-2013, 2013.

Carlile, M. J., Watkinson, S. C., and Gooday, G. W.: The Fungi, Second Edi., Academic Press, London, United Kingdom and San Diego, CA, USA, 2001.

Charlson, R. J., Lovelock, J. E., Andreae, M. O., and Warren, S. G.: Oceanic phytoplankton, atmospheric sulphur, cloud albedo and climate, Nature, 326, 655-661, doi:10.1038/326655a0, 1987.

Chou, C., Stetzer, O., Weingartner, E., Jurányi, Z., Kanji, Z. A., and Lohmann, U.: Ice nuclei properties within a Saharan dust event at the Jungfraujoch in the Swiss Alps, Atmos. Chem. Phys., 11, 4725-4738, doi:10.5194/acp-11-4725-2011, 2011.

Christner, B. C., Morris, C. E., Foreman, C. M., Cai, R., and Sands, D. C.: Ubiquity of Biological Ice Nucleators in Snowfall, Science, 319, 1214, doi:10.1126/science.1149757, 2008.

Conen, F., Morris, C. E., Leifeld, J., Yakutin, M. V., and Alewell, C.: Biological residues define the ice nucleation properties of soil dust, Atmos. Chem. Phys., 11, 9643-9648, doi:10.5194/acp-119643-2011, 2011.

Cooper, W. A.: Ice initiation in natural clouds, Meteor. Mon., 21, 29-32, doi:10.1175/0065-9401-21.43.29, 1986.

Corbin, J. C., Rehbein, P. J. G., Evans, G. J., and Abbatt, J. P. D.: Combustion particles as ice nuclei in an urban environment: Evidence from single-particle mass spectrometry, Atmos. Environ., 51, 286-292, doi:10.1016/j.atmosenv.2012.01.007, 2012.

Costa, T. S., Gonçalves, F. L. T., Yamasoe, M. A., Martins, J. A., and Morris, C. E.: Bacterial ice nuclei impact cloud lifetime and radiative properties and reduce atmospheric heat loss in the BRAMS simulation model, Environ. Res. Lett., 9, 084020, doi:10.1088/1748-9326/9/8/084020, 2014.

Cozic, J., Mertes, S., Verheggen, B., Cziczo, D. J., Gallavardin, S. J., Walter, S., Baltensperger, U., and Weingartner, E.: Black carbon enrichment in atmospheric ice particle residuals observed in lower tropospheric mixed phase clouds, J. Geophys. Res., 113, D15209, doi:10.1029/2007JD009266, 2008.

Creamean, J. M., Suski, K. J., Rosenfeld, D., Cazorla, A., DeMott, P. J., Sullivan, R. C., White, A. B., Ralph, F. M., Minnis, P., Comstock, J. M., Tomlinson, J. M., and Prather, K. A.: Dust and Biological Aerosols from the Sahara and Asia Influence Precipitation in the Western U.S., Science, 339, 1572-1578, doi:10.1126/science.1227279, 2013.

Cziczo, D. J., Murphy, D. M., Hudson, P. K., and Thomson, D. S.: Single particle measurements of the chemical composition of cir- 
rus ice residue during CRYSTAL-FACE, J. Geophys. Res., 109, D04201, doi:10.1029/2003JD004032, 2004.

Cziczo, D. J., Froyd, K. D., Hoose, C., Jensen, E. J., Diao, M., Zondlo, M. A., Smith, J. B., Twohy, C. H., and Murphy, D. M.: Clarifying the Dominant Sources and Mechanisms of Cirrus Cloud Formation, Science, 340, 1320-1324, doi:10.1126/science.1234145, 2013.

Dancey, C. P. and Reidy, J.: Statistics Without Maths for Psychology, Pearson Education Limited, Essex, England, 175-184, 2011.

DeMott, P. J., Sassen, K., Poellot, M. R., Baumgardner, D., Rogers, D. C., Brooks, S. D., Prenni, A. J., and Kreidenweis, S. M.: African dust aerosols as atmospheric ice nuclei, Geophys. Res. Lett., 30, 1732, doi:10.1029/2003GL017410, 2003.

DeMott, P. J., Petters, M. D., Prenni, A. J., Carrico, C. M., Kreidenweis, S. M., Collett Jr., J. L., and Moosmüller, H.: Ice nucleation behavior of biomass combustion particles at cirrus temperatures, J. Geophys. Res., 114, D16205, doi:10.1029/2009JD012036, 2009.

DeMott, P. J., Prenni, A. J., Liu, X., Kreidenweis, S. M., Petters, M. D., Twohy, C. H., Richardson, M. S., Eidhammer, T., and Rogers, D. C.: Predicting global atmospheric ice nuclei distributions and their impacts on climate, P. Natl. Acad. Sci. USA, 107, 1121711222, doi:10.1073/pnas.0910818107, 2010.

DeMott, P. J., Hill, T. C. J., McCluskey, C. S., Prather, K. A., Collins, D. B., Sullivan, R. C., Ruppel, M. J., Mason, R. H., Irish, V. E., Lee, T., Hwang, C. Y., Rhee, T. S., Snider, J. R., McMeeking, G. R., Dhaniyala, S., Lewis, E. R., Wentzell, J., Abbatt, J. P. D., Lee, C., Sultana, C. M., Ault, A. P., Axson, J. I., Martinez, M. D., Venero, I., Figueroa, G. S., Stokes, M. D., Deane, G. B., Mayol-Bracero, O. L., Grassian, V. H., Bertram, T. H., Bertram, A. K., Moffett, B. F., and Franc, G. D.: Sea spray aerosol as a unique source of ice nucleating particles, submitted, 2015.

Després, V. R., Huffman, J. A., Burrows, S. M., Hoose, C., Safatov, A. S., Buryak, G., Fröhlich-Nowoisky, J., Elbert, W., Andreae, M. O., Pöschl, U. and Jaenicke, R.: Primary biological aerosol particles in the atmosphere: a review, Tellus B, 64, 15598, doi:10.3402/tellusb.v64i0.15598, 2012.

Diehl, K. and Mitra, S. K.: A laboratory study of the effects of a kerosene-burner exhaust on ice nucleation and the evaporation rate of ice crystals, Atmos. Environ., 32, 3145-3151, doi:10.1016/S1352-2310(97)00467-6, 1998.

Diehl, K., Quick, C., Matthias-Maser, S., Mitra, S. K., and Jaenicke, R.: The ice nucleating ability of pollen: Part I. Laboratory studies in deposition and condensation freezing modes, Atmos. Res., 58, 75-87, doi:10.1016/S0169-8095(01)00091-6, 2001.

Diehl, K., Matthias-Maser, S., Jaenicke, R., and Mitra, S. K.: The ice nucleating ability of pollen: Part II, Laboratory studies in immersion and contact freezing modes, Atmos. Res., 61, 125-133, doi:10.1016/S0169-8095(01)00132-6, 2002.

Draxler, R. R. and Rolph, G. D.: HYSPLIT (HYbrid SingleParticle Lagrangian Integrated Trajectory) Model access via NOAA ARL READY Website, NOAA Air Resources Laboratory, Silver Spring, MD, available at: http://ready.arl.noaa.gov/ HYSPLIT.php, last access: 27 May 2014.

Dymarska, M., Murray, B. J., Sun, L., Eastwood, M. L., Knopf, D. A., and Bertram, A. K.: Deposition ice nucleation on soot at temperatures relevant for the lower troposphere, J. Geophys. Res., 111, D04204, doi:10.1029/2005JD006627, 2006.
Ebert, M., Worringen, A., Benker, N., Mertes, S., Weingartner, E., and Weinbruch, S.: Chemical composition and mixing-state of ice residuals sampled within mixed phase clouds, Atmos. Chem. Phys., 11, 2805-2816, doi:10.5194/acp-11-2805-2011, 2011.

Field, P. R., Möhler, O., Connolly, P., Krämer, M., Cotton, R., Heymsfield, A. J., Saathoff, H., and Schnaiter, M.: Some ice nucleation characteristics of Asian and Saharan desert dust, Atmos. Chem. Phys., 6, 2991-3006, doi:10.5194/acp-6-2991-2006, 2006.

Field, P. R., Heymsfield, A. J., Shipway, B. J., DeMott, P. J., Pratt, K. A., Rogers, D. C., Stith, J., and Prather, K. A.: Ice in Clouds Experiment-Layer Clouds, Part II: Testing Characteristics of Heterogeneous Ice Formation in Lee Wave Clouds, J. Atmos. Sci., 69, 1066-1079, doi:10.1175/JAS-D-11-026.1, 2012.

Fletcher, N. H.: Ice-forming nuclei in the atmosphere, in: The Physics of Rainclouds, Cambridge University Press, Cambridge, United Kingdom, Chapter 9, 1962.

Friedman, B., Kulkarni, G., Beránek, J., Zelenyuk, A., Thornton, J. A., and Cziczo, D. J.: Ice nucleation and droplet formation by bare and coated soot particles, J. Geophys. Res., 116, D17203, doi:10.1029/2011JD015999, 2011.

Fröhlich-Nowoisky, J., Hill, T. C. J., Pummer, B. G., Yordanova, P., Franc, G. D., and Pöschl, U.: Ice nucleation activity in the widespread soil fungus Mortierella alpina, Biogeosciences, 12, 1057-1071, doi:10.5194/bg-12-1057-2015, 2015.

Gabey, A. M., Gallagher, M. W., Whitehead, J., Dorsey, J. R., Kaye, P. H., and Stanley, W. R.: Measurements and comparison of primary biological aerosol above and below a tropical forest canopy using a dual channel fluorescence spectrometer, Atmos. Chem. Phys., 10, 4453-4466, doi:10.5194/acp-10-4453-2010, 2010.

Gabey, A. M., Stanley, W. R., Gallagher, M. W., and Kaye, P. H.: The fluorescence properties of aerosol larger than $0.8 \mu \mathrm{m}$ in urban and tropical rainforest locations, Atmos. Chem. Phys., 11, 54915504, doi:10.5194/acp-11-5491-2011, 2011.

Gadi, R., Kulshrestha, U. C., Sarkar, A. K., Garg, S. C., and Parashar, D. C.: Emissions of $\mathrm{SO}_{2}$ and $\mathrm{NO}_{x}$ from biofuels in India, Tellus B, 55, 787-795, doi:10.1034/j.16000889.2003.00065.x, 2003.

Galanter, M., Levy II, H., and Carmichael, G. R.: Impacts of biomass burning on tropospheric $\mathrm{CO}, \mathrm{NO}_{x}$, and $\mathrm{O}_{3}$, J. Geophys. Res., 105, 6633-6653, doi:10.1029/1999JD901113, 2000.

Garcia, E., Hill, T. C. J., Prenni, A. J., DeMott, P. J., Franc, G. D., and Kreidenweis, S. M.: Biogenic ice nuclei in boundary layer air over two U.S. High Plains agricultural regions, J. Geophys. Res., 117, D18209, doi:10.1029/2012JD018343, 2012.

Gaston, C. J., Pratt, K. A., Qin, X., and Prather, K. A.: Real-Time Detection and Mixing State of Methanesulfonate in Single Particles at an Inland Urban Location during a Phytoplankton Bloom, Environ. Sci. Technol., 44, 1566-1572, doi:10.1021/es902069d, 2010.

Gorbunov, B., Baklanov, A., Kakutkina, N., Windsor, H. L., and Toumi, R.: Ice nucleation on soot particles, J. Aerosol Sci., 32, 199-215, doi:10.1016/s0021-8502(00)00077-x, 2001.

Hader, J. D., Wright, T. P., and Petters, M. D.: Contribution of pollen to atmospheric ice nuclei concentrations, Atmos. Chem. Phys., 14, 5433-5449, doi:10.5194/acp-14-5433-2014, 2014.

Haga, D. I., Iannone, R., Wheeler, M. J., Mason, R., Polishchuk, E. A., Fetch Jr., T., van der Kamp, B. J., McKendry, I. G., and Bertram, A. K.: Ice nucleation properties of rust and bunt fungal 
spores and their transport to high altitudes, where they can cause heterogeneous freezing, J. Geophys. Res.-Atmos., 118, 72607272, doi:10.1002/jgrd.50556, 2013.

Haga, D. I., Burrows, S. M., Iannone, R., Wheeler, M. J., Mason, R. H., Chen, J., Polishchuk, E. A., Pöschl, U., and Bertram, A. K.: Ice nucleation by fungal spores from the classes Agaricomycetes, Ustilaginomycetes, and Eurotiomycetes, and the effect on the atmospheric transport of these spores, Atmos. Chem. Phys., 14, 8611-8630, doi:10.5194/acp-14-8611-2014, 2014.

Healy, D. A., O'Connor, D. J., Burke, A. M., and Sodeau, J. R.: A laboratory assessment of the Waveband Integrated Bioaerosol Sensor (WIBS-4) using individual samples of pollen and fungal spore material, Atmos. Environ., 60, 534-543, doi:10.1016/j.atmosenv.2012.06.052, 2012a.

Healy, D. A., O'Connor, D. J., and Sodeau, J. R.: Measurement of the particle counting efficiency of the "Waveband Integrated Bioaerosol Sensor" model number 4 (WIBS-4), J. Aerosol Sci., 47, 94-99, doi:10.1016/j.jaerosci.2012.01.003, 2012b.

Healy, D. A., Huffman, J. A., O'Connor, D. J., Pöhlker, C., Pöschl, U., and Sodeau, J. R.: Ambient measurements of biological aerosol particles near Killarney, Ireland: a comparison between real-time fluorescence and microscopy techniques, Atmos. Chem. Phys., 14, 8055-8069, doi:10.5194/acp-14-80552014, 2014.

Hill, T. C. J., Moffett, B. F., DeMott, P. J., Georgakopoulos, D. G., Stump, W. L., and Franc, G. D.: Measurement of Ice Nucleation-Active Bacteria on Plants and in Precipitation by Quantitative PCR, Appl. Environ. Microbiol., 80, 1256-1267, doi:10.1128/AEM.02967-13, 2014.

Hiranuma, N., Möhler, O., Yamashita, K., Tajiri, T., Saito, A., Kiselev, A., Hoffmann, N., Hoose, C., Jantsch, E., Koop, T., and Murakami, M.: Ice nucleation by cellulose and its potential contribution to ice formation in clouds, Nat. Geosci., 8, 273-277, doi:10.1038/ngeo2374, 2015.

Hoose, C. and Möhler, O.: Heterogeneous ice nucleation on atmospheric aerosols: a review of results from laboratory experiments, Atmos. Chem. Phys., 12, 9817-9854, doi:10.5194/acp-12-98172012, 2012.

Hoose, C., Kristjánsson, J. E., and Burrows, S. M.: How important is biological ice nucleation in clouds on a global scale?, Environ. Res. Lett., 5, 024009, doi:10.1088/1748-9326/5/2/024009, 2010a.

Hoose, C., Kristjánsson, J. E., Chen, J.-P., and Hazra, A.: A Classical-Theory-Based Parameterization of Heterogeneous Ice Nucleation by Mineral Dust, Soot, and Biological Particles in a Global Climate Model, J. Atmos. Sci., 67, 2483-2503, doi:10.1175/2010JAS3425.1, 2010b.

Huffman, J. A., Treutlein, B., and Pöschl, U.: Fluorescent biological aerosol particle concentrations and size distributions measured with an Ultraviolet Aerodynamic Particle Sizer (UVAPS) in Central Europe, Atmos. Chem. Phys., 10, 3215-3233, doi:10.5194/acp-10-3215-2010, 2010.

Huffman, J. A., Sinha, B., Garland, R. M., Snee-Pollmann, A., Gunthe, S. S., Artaxo, P., Martin, S. T., Andreae, M. O., and Pöschl, U.: Size distributions and temporal variations of biological aerosol particles in the Amazon rainforest characterized by microscopy and real-time UV-APS fluorescence techniques during AMAZE-08, Atmos. Chem. Phys., 12, 11997-12019, doi:10.5194/acp-12-11997-2012, 2012.
Huffman, J. A., Prenni, A. J., DeMott, P. J., Pöhlker, C., Mason, R. H., Robinson, N. H., Fröhlich-Nowoisky, J., Tobo, Y., Després, V. R., Garcia, E., Gochis, D. J., Harris, E., Müller-Germann, I., Ruzene, C., Schmer, B., Sinha, B., Day, D. A., Andreae, M. O., Jimenez, J. L., Gallagher, M., Kreidenweis, S. M., Bertram, A. K., and Pöschl, U.: High concentrations of biological aerosol particles and ice nuclei during and after rain, Atmos. Chem. Phys., 13, 6151-6164, doi:10.5194/acp-13-6151-2013, 2013.

Iannone, R., Chernoff, D. I., Pringle, A., Martin, S. T., and Bertram, A. K.: The ice nucleation ability of one of the most abundant types of fungal spores found in the atmosphere, Atmos. Chem. Phys., 11, 1191-1201, doi:10.5194/acp-11-1191-2011, 2011.

Jayaweera, K. and Flanagan, P.: Investigations on biogenic ice nuclei in the Arctic atmosphere, Geophys. Res. Lett., 9, 94-97, doi:10.1029/GL009i001p00094, 1982.

Jiang, H., Yin, Y., Su, H., Shan, Y., and Gao, R.: The characteristics of atmospheric ice nuclei measured at the top of Huangshan (the Yellow Mountains) in Southeast China using a newly built static vacuum water vapor diffusion chamber, Atmos. Res., 153, 200 208, doi:10.1016/j.atmosres.2014.08.015, 2015.

Joly, M., Amato, P., Deguillaume, L., Monier, M., Hoose, C., and Delort, A.-M.: Quantification of ice nuclei active at near $0{ }^{\circ} \mathrm{C}$ temperatures in low-altitude clouds at the Puy de Dôme atmospheric station, Atmos. Chem. Phys., 14, 8185-8195, doi:10.5194/acp-14-8185-2014, 2014.

Kamphus, M., Ettner-Mahl, M., Klimach, T., Drewnick, F., Keller, L., Cziczo, D. J., Mertes, S., Borrmann, S., and Curtius, J.: Chemical composition of ambient aerosol, ice residues and cloud droplet residues in mixed-phase clouds: single particle analysis during the Cloud and Aerosol Characterization Experiment (CLACE 6), Atmos. Chem. Phys., 10, 8077-8095, doi:10.5194/acp-10-8077-2010, 2010.

Kanji, Z. A. and Abbatt, J. P. D.: Ice Nucleation onto Arizona Test Dust at Cirrus Temperatures: Effect of Temperature and Aerosol Size on Onset Relative Humidity, J. Phys. Chem. A, 114, 935941, doi:10.1021/jp908661m, 2010.

Kärcher, B., Möhler, O., DeMott, P. J., Pechtl, S., and Yu, F.: Insights into the role of soot aerosols in cirrus cloud formation, Atmos. Chem. Phys., 7, 4203-4227, doi:10.5194/acp-7-4203-2007, 2007.

Kaye, P., Stanley, W. R., Hirst, E., Foot, E. V, Baxter, K. L., and Barrington, S. J.: Single particle multichannel bioaerosol fluorescence sensor, Opt. Express, 13, 3583-3593, doi:10.1364/OPEX.13.003583, 2005.

Keller, M. D.: Dimethyl Sulfide Production and Marine Phytoplankton: The Importance of Species Composition and Cell Size, Biol. Oceanogr., 6, 375-382, 1989.

Kettle, A. J., Andreae, M. O., Amouroux, D., Andreae, T. W., Bates, T. S., Berresheim, H., Bingemer, H., Boniforti, R., Curran, M., DiTullio, G. R., Helas, G., Jones, G. B., Keller, M. D., Kiene, R. P., Leck, C., Levasseur, M., Malin, G., Maspero, M., Matrai, P., McTaggart, A. R., Mihalopoulos, N., Nguyen, B. C., Novo, A., Putaud, J. P., Rapsomanikis, S., Roberts, G., Schebeske, G., Sharma, S., Simó, R., Staubes, R., Turner, S., and Uher, G.: A global database of sea surface dimethylsulfide (DMS) measurements and a procedure to predict sea surface DMS as a function of latitude, longitude, and month, Global Biogeochem. Cy., 13, 399-444, doi:10.1029/1999GB900004, 1999. 
Klein, H., Nickovic, S., Haunold, W., Bundke, U., Nillius, B., Ebert, M., Weinbruch, S., Schuetz, L., Levin, Z., Barrie, L. A., and Bingemer, H.: Saharan dust and ice nuclei over Central Europe, Atmos. Chem. Phys., 10, 10211-10221, doi:10.5194/acp10-10211-2010, 2010.

Knopf, D. A. and Koop, T.: Heterogeneous nucleation of ice on surrogates of mineral dust, J. Geophys. Res., 111, D12201, doi:10.1029/2005JD006894, 2006.

Knopf, D. A., Alpert, P. A., Wang, B., and Aller, J. Y.: Stimulation of ice nucleation by marine diatoms, Nat. Geosci., 4, 88-90, doi:10.1038/ngeo1037, 2011

Knopf, D. A., Alpert, P. A., Wang, B., O’Brien, R. E., Kelly, S. T., Laskin, A., Gilles, M. K., and Moffet, R. C.: Microspectroscopic imaging and characterization of individually identified ice nucleating particles from a case field study, J. Geophys. Res.-Atmos., 119, 10365-10381, doi:10.1002/2014JD021866, 2014.

Koop, T., Luo, B., Biermann, U. M., Crutzen, P. J., and Peter, T.: Freezing of $\mathrm{HNO}_{3} / \mathrm{H}_{2} \mathrm{SO}_{4} / \mathrm{H}_{2} \mathrm{O}$ solutions at stratospheric temperatures: Nucleation statistics and experiments, J. Phys. Chem. A, 101, 1117-1133, doi:10.1021/jp9626531, 1997.

Koop, T., Kapilashrami, A., Molina, L. T., and Molina, M. J.: Phase transitions of sea-salt/water mixtures at low temperatures: Implications for ozone chemistry in the polar marine boundary layer, J. Geophys. Res., 105, 26393-26402, doi:10.1029/2000JD900413, 2000

Kottek, M., Grieser, J., Beck, C., Rudolf, B., and Rubel, F.: World Map of the Köppen-Geiger climate classification updated, Meteorol. Z., 15, 259-263, doi:10.1127/0941-2948/2006/0130, 2006.

Kozloff, L. M., Schofield, M. A., and Lute, M.: Ice nucleating activity of Pseudomonas syringae and Erwinia herbicola, J. Bacteriol., 153, 222-231, 1983.

Kulkarni, G. and Dobbie, S.: Ice nucleation properties of mineral dust particles: determination of onset RHi, IN active fraction, nucleation time-lag, and the effect of active sites on contact angles, Atmos. Chem. Phys., 10, 95-105, doi:10.5194/acp-10-95-2010, 2010.

Lee, H. J., Laskin, A., Laskin, J., and Nizkorodov, S. A.: ExcitationEmission Spectra and Fluorescence Quantum Yields for Fresh and Aged Biogenic Secondary Organic Aerosols, Environ. Sci. Technol., 47, 5763-5770, doi:10.1021/es400644c, 2013.

Leslie, J. F. and Summerell, B. A.: The Fusarium Laboratory Manual, Blackwell Publishing, Ames, Iowa, USA, 2006.

Lin, J. C., Matsui, T., Pielke Sr., R. A. and Kummerow, C.: Effects of biomass-burning-derived aerosols on precipitation and clouds in the Amazon Basin: a satellite-based empirical study, J. Geophys. Res., 111, D19204, doi:10.1029/2005JD006884, 2006.

Lindow, S. E., Arny, D. C., and Upper, C. D.: Erwinia herbicola: A Bacterial Ice Nucleus Active in Increasing Frost Injury to Corn, Phytopathology, 68, 523-527, 1978.

Liu, X., Penner, J. E., and Wang, M.: Influence of anthropogenic sulfate and black carbon on upper tropospheric clouds in the NCAR CAM3 model coupled to the IMPACT global aerosol model, J. Geophys. Res., 114, D03204, doi:10.1029/2008JD010492, 2009.

Lohmann, U.: A glaciation indirect aerosol effect caused by soot aerosols, Geophys. Res. Lett., 29, 1052, doi:10.1029/2001GL014357, 2002.

Lüönd, F., Stetzer, O., Welti, A., and Lohmann, U.: Experimental study on the ice nucleation ability of size-selected kaolinite par- ticles in the immersion mode, J. Geophys. Res., 115, D14201, doi:10.1029/2009JD012959, 2010.

Maheshwari, R.: Fungi: Experimental Methods in Biology, CRC Press, Taylor \& Francis Group, Boca Raton, Florida, USA, 2005.

Maki, L. R. and Willoughby, K. J.: Bacteria as Biogenic Sources of Freezing Nuclei, J. Appl. Meteorol., 17, 1049-1053, 1978.

Maki, L. R., Galyan, E. L., Chang-Chien, M.-M., and Caldwell, D. R.: Ice nucleation induced by pseudomonas syringae, Appl. Microbiol., 28, 456-459, 1974.

Marcolli, C., Gedamke, S., Peter, T., and Zobrist, B.: Efficiency of immersion mode ice nucleation on surrogates of mineral dust, Atmos. Chem. Phys., 7, 5081-5091, doi:10.5194/acp-7-50812007, 2007.

Maring, H., Savoie, D. L., Izaguirre, M. A., Custals, M., and Reid, J. S.: Mineral dust aerosol size distribution change during atmospheric transport, J. Geophys. Res., 108, 8592, doi:10.1029/2002JD002536, 2003.

Marple, V. A., Rubow, K. L., and Behm, S. M.: A Microorifice Uniform Deposit Impactor (MOUDI): Description, Calibration, and Use, Aerosol Sci. Technol., 14, 434-446, doi:10.1080/02786829108959504, 1991.

Mason, B. J. and Maybank, J.: Ice-nucleating properties of some natural mineral dusts, Q. J. R. Meteorol. Soc., 84, 235-241, doi:10.1002/qj.49708436104, 1958.

Mason, R. H., Chou, C., McCluskey, C. S., Levin, E. J. T., Schiller, C. L., Hill, T. C. J., Huffman, J. A., DeMott, P. J., and Bertram, A. K.: The micro-orifice uniform deposit impactordroplet freezing technique (MOUDI-DFT) for measuring concentrations of ice nucleating particles as a function of size: improvements and initial validation, Atmos. Meas. Tech., 8, 24492462, doi:10.5194/amt-8-2449-2015, 2015.

McCluskey, C. S., DeMott, P. J., Prenni, A. J., Levin, E. J. T., McMeeking, G. R., Sullivan, A. P., Hill, T. C. J., Nakao, S., Carrico, C. M., and Kreidenweis, S. M.: Characteristics of atmospheric ice nucleating particles associated with biomass burning in the US: Prescribed burns and wildfires, J. Geophys. Res.Atmos., 119, 10458-10470, doi:10.1002/2014JD021980, 2014.

McKendry, I. G., Christensen, E., Schiller, C. L., Vingarzan, R., Macdonald, A. M., and Li, Y.: Low Ozone Episodes at Amphitrite Point Marine Boundary Layer Observatory, British Columbia, Canada, Atmosphere-Ocean, 52, 271-280, doi:10.1080/07055900.2014.910164, 2014.

Meyers, M. P., DeMott, P. J., and Cotton, W. R.: New primary icenucleation parameterizations in an explicit cloud model, J. Appl. Meteorol., 31, 708-721, 1992.

Möhler, O., Büttner, S., Linke, C., Schnaiter, M., Saathoff, H., Stetzer, O., Wagner, R., Krämer, M., Mangold, A., Ebert, V., and Schurath, U.: Effect of sulfuric acid coating on heterogeneous ice nucleation by soot aerosol particles, J. Geophys. Res., 110, D11210, doi:10.1029/2004JD005169, 2005.

Möhler, O., Field, P. R., Connolly, P., Benz, S., Saathoff, H., Schnaiter, M., Wagner, R., Cotton, R., Krämer, M., Mangold, A., and Heymsfield, A. J.: Efficiency of the deposition mode ice nucleation on mineral dust particles, Atmos. Chem. Phys., 6, 30073021, doi:10.5194/acp-6-3007-2006, 2006.

Möhler, O., DeMott, P. J., Vali, G., and Levin, Z.: Microbiology and atmospheric processes: the role of biological particles in cloud physics, Biogeosciences, 4, 1059-1071, doi:10.5194/bg-4-10592007, 2007. 
Monahan, E. C. and Muircheartaigh, I. Ó.: Optimal power-law description of oceanic whitecap coverage dependence on wind speed, J. Phys. Oceanogr., 10, 2094-2099, 1980.

Morris, C. E., Sands, D. C., Vinatzer, B. A., Glaux, C., Guilbaud, C., Buffière, A., Yan, S., Dominguez, H., and Thompson, B. M.: The life history of the plant pathogen Pseudomonas syringae is linked to the water cycle, ISME J., 2, 321-334, doi:10.1038/ismej.2007.113, 2008.

Morris, C. E., Sands, D. C., Glaux, C., Samsatly, J., Asaad, S., Moukahel, A. R., Gonçalves, F. L. T., and Bigg, E. K.: Urediospores of rust fungi are ice nucleation active at $>-10^{\circ} \mathrm{C}$ and harbor ice nucleation active bacteria, Atmos. Chem. Phys., 13, 4223-4233, doi:10.5194/acp-13-4223-2013, 2013.

Murray, B. J., Broadley, S. L., Wilson, T. W., Atkinson, J. D., and Wills, R. H.: Heterogeneous freezing of water droplets containing kaolinite particles, Atmos. Chem. Phys., 11, 4191-4207, doi:10.5194/acp-11-4191-2011, 2011.

Murray, B. J., O’Sullivan, D., Atkinson, J. D., and Webb, M. E.: Ice nucleation by particles immersed in supercooled cloud droplets, Chem. Soc. Rev., 41, 6519-6554, doi:10.1039/c2cs35200a, 2012.

National Data Buoy Center: National Oceanic and Atmospheric Administration, http://www.ndbc.noaa.gov/station_page. php?station=46206 (last access: 9 December 2014), 2013.

Niedermeier, D., Hartmann, S., Shaw, R. A., Covert, D., Mentel, T. F., Schneider, J., Poulain, L., Reitz, P., Spindler, C., Clauss, T., Kiselev, A., Hallbauer, E., Wex, H., Mildenberger, K., and Stratmann, F.: Heterogeneous freezing of droplets with immersed mineral dust particles - measurements and parameterization, Atmos. Chem. Phys., 10, 3601-3614, doi:10.5194/acp-10-36012010, 2010.

O’Dowd, C. D. and de Leeuw, G.: Marine aerosol production: a review of the current knowledge, Philos. Trans. R. Soc. A, 365, 1753-1774, doi:10.1098/rsta.2007.2043, 2007.

O'Sullivan, D., Murray, B. J., Malkin, T. L., Whale, T. F., Umo, N. S., Atkinson, J. D., Price, H. C., Baustian, K. J., Browse, J., and Webb, M. E.: Ice nucleation by fertile soil dusts: relative importance of mineral and biogenic components, Atmos. Chem. Phys., 14, 1853-1867, doi:10.5194/acp-14-1853-2014, 2014.

O’Sullivan, D., Murray, B. J., Ross, J. F., Whale, T. F., Price, H. C., Atkinson, J. D., Umo, N. S., and Webb, M. E.: The relevance of nanoscale biological fragments for ice nucleation in clouds, Sci. Rep., 5, 8082, doi:10.1038/srep08082, 2015.

Pan, Y.-L., Holler, S., Chang, R. K., Hill, S. C., Pinnick, R. G., Niles, S., Bottiger, J. R., and Bronk, B. V: Real-time detection and characterization of individual flowing airborne biological particles: fluorescence spectra and elastic scattering measurements, P. Soc. Photo-Opt. Ins., 3855, 117-125, doi:10.1117/12.371270, 1999.

Parker, L. V, Sullivan, C. W., Forest, T. W., and Ackley, S. F.: Ice nucleation activity of antarctic marine microorganisms, Antarct. J. USA, 20, 126-127, 1985.

Penner, J. E., Chen, Y., Wang, M., and Liu, X.: Possible influence of anthropogenic aerosols on cirrus clouds and anthropogenic forcing, Atmos. Chem. Phys., 9, 879-896, doi:10.5194/acp-9-8792009, 2009.

Petters, M. D., Parsons, M. T., Prenni, A. J., Demott, P. J., Kreidenweis, S. M., Carrico, C. M., Sullivan, A. P., McMeeking, G. R., Levin, E., Wold, C. E., Collett Jr., J. L., and Moosmüller, H.: Ice nuclei emissions from biomass burning, J. Geophys. Res., 114, D07209, doi:10.1029/2008JD011532, 2009.

Petzold, A. and Schönlinner, M.: Multi-angle absorption photometry - a new method for the measurement of aerosol light absorption and atmospheric black carbon, J. Aerosol Sci., 35, 421-441, doi:10.1016/j.jaerosci.2003.09.005, 2004.

Petzold, A., Kramer, H., and Schönlinner, M.: Continuous Measurement of Atmospheric Black Carbon Using a Multi-angle Absorption Photometer, Environ. Sci. Pollut. Res., 4, 78-82, 2002.

Petzold, A., Schloesser, H., Sheridan, P. J., Arnott, W. P., Ogren, J. A., and Virkkula, A.: Evaluation of Multiangle Absorption Photometry for Measuring Aerosol Light Absorption, Aerosol Sci. Technol., 39, 40-51, doi:10.1080/027868290901945, 2005.

Petzold, A., Ogren, J. A., Fiebig, M., Laj, P., Li, S.-M., Baltensperger, U., Holzer-Popp, T., Kinne, S., Pappalardo, G., Sugimoto, N., Wehrli, C., Wiedensohler, A., and Zhang, X.-Y.: Recommendations for reporting "black carbon" measurements, Atmos. Chem. Phys., 13, 8365-8379, doi:10.5194/acp-13-83652013, 2013.

Phillips, V. T. J., Andronache, C., Christner, B., Morris, C. E., Sands, D. C., Bansemer, A., Lauer, A., McNaughton, C., and Seman, C.: Potential impacts from biological aerosols on ensembles of continental clouds simulated numerically, Biogeosciences, 6 , 987-1014, doi:10.5194/bg-6-987-2009, 2009.

Phinney, L., Leaitch, W. R., Lohmann, U., Boudries, H., Worsnop, D. R., Jayne, J. T., Toom-Sauntry, D., Wadleigh, M., Sharma, S., and Shantz, N.: Characterization of the aerosol over the subarctic north east Pacific Ocean, Deep-Sea Res. Pt. II, 53, 24102433, doi:10.1016/j.dsr2.2006.05.044, 2006.

Pöhlker, C., Huffman, J. A., and Pöschl, U.: Autofluorescence of atmospheric bioaerosols - fluorescent biomolecules and potential interferences, Atmos. Meas. Tech., 5, 37-71, doi:10.5194/amt-537-2012, 2012.

Pouleur, S., Richard, C., Martin, J.-G., and Antoun, H.: Ice Nucleation Activity in Fusarium acuminatum and Fusarium avenaceum, Appl. Environ. Microbiol., 58, 2960-2964, 1992.

Prather, K. A., Bertram, T. H., Grassian, V. H., Deane, G. B., Stokes, M. D., DeMott, P. J., Aluwihare, L. I., Palenik, B. P., Azam, F., Seinfeld, J. H., Moffet, R. C., Molina, M. J., Cappa, C. D., Geiger, F. M., Roberts, G. C., Russell, L. M., Ault, A. P., Baltrusaitis, J., Collins, D. B., Corrigan, C. E., Cuadra-Rodriguez, L. A., Ebben, C. J., Forestieri, S. D., Guasco, T. L., Hersey, S. P., Kim, M. J., Lambert, W. F., Modini, R. L., Mui, W., Pedler, B. E., Ruppel, M. J., Ryder, O. S., Schoepp, N. G., Sullivan, R. C., and Zhao, D.: Bringing the ocean into the laboratory to probe the chemical complexity of sea spray aerosol, P. Natl. Acad. Sci. USA, 110, 7550-7555, doi:10.1073/pnas.1300262110, 2013.

Pratt, K. A., DeMott, P. J., French, J. R., Wang, Z., Westphal, D. L., Heymsfield, A. J., Twohy, C. H., Prenni, A. J., and Prather, K. A.: In situ detection of biological particles in cloud ice-crystals, Nat. Geosci., 2, 398-401, doi:10.1038/ngeo521, 2009.

Prenni, A. J., Petters, M. D., Kreidenweis, S. M., Heald, C. L., Martin, S. T., Artaxo, P., Garland, R. M., Wollny, A. G., and Pöschl, U.: Relative roles of biogenic emissions and Saharan dust as ice nuclei in the Amazon basin, Nat. Geosci., 2, 402-405, doi:10.1038/ngeo517, 2009.

Prenni, A. J., Tobo, Y., Garcia, E., DeMott, P. J., Huffman, J. A., McCluskey, C. S., Kreidenweis, S. M., Prenni, J. E., Pöhlker, C. and Pöschl, U.: The impact of rain on ice nuclei populations at 
a forested site in Colorado, Geophys. Res. Lett., 40, 227-231, doi:10.1029/2012GL053953, 2013.

Pummer, B. G., Bauer, H., Bernardi, J., Bleicher, S., and Grothe, H.: Suspendable macromolecules are responsible for ice nucleation activity of birch and conifer pollen, Atmos. Chem. Phys., 12, 2541-2550, doi:10.5194/acp-12-2541-2012, 2012.

Ribalet, F., Marchetti, A., Hubbard, K. A., Brown, K., Durkin, C. A., Morales, R., Robert, M., Swalwell, J. E., Tortell, P. D. and Armbrust, E. V.: Unveiling a phytoplankton hotspot at a narrow boundary between coastal and offshore waters, P. Natl. Acad. Sci. USA, 107, 16571-16576, doi:10.1073/pnas.1005638107, 2010.

Richard, C., Martin, J.-G., and Pouleur, S.: Ice nucleation activity identified in some phytopathogenic Fusarium species, Phytoprotection, 77, 83-92, doi:10.7202/706104ar, 1996.

Richardson, M. S., DeMott, P. J., Kreidenweis, S. M., Cziczo, D. J., Dunlea, E. J., Jimenez, J. L., Thomson, D. S., Ashbaugh, L. L., Borys, R. D., Westphal, D. L., Casuccio, G. S., and Lersch, T. L.: Measurements of heterogeneous ice nuclei in the western United States in springtime and their relation to aerosol characteristics, J. Geophys. Res., 112, D02209, doi:10.1029/2006JD007500, 2007.

Rogers, D. C., DeMott, P. J., Kreidenweis, S. M., and Chen, Y.: Measurements of ice nucleating aerosols during SUCCESS, Geophys. Res. Lett., 25, 1383-1386, doi:10.1029/97GL03478, 1998.

Saltzman, E. S., Savoie, D. L., Prospero, J. M., and Zika, R. G.: Methanesulfonic acid and non-sea-salt sulfate in Pacific air: Regional and seasonal variations, J. Atmos. Chem., 4, 227-240, doi:10.1007/BF00052002, 1986.

Savoie, D. L., Prospero, J. M., Arimoto, R., and Duce, R. A.: Nonsea-salt sulfate and methanesulfonate at American Samoa, J. Geophys. Res., 99, 3587-3596, doi:10.1029/93JD03337, 1994.

Schnell, R. C.: Ice nuclei produced by laboratory cultured marine phytoplankton, Geophys. Res. Lett., 2, 500-502, doi:10.1029/GL002i011p00500, 1975.

Schnell, R. C.: Ice Nuclei in Seawater, Fog Water and Marine Air off the Coast of Nova Scotia: Summer 1975, J. Atmos. Sci., 34, 1299-1305, 1977.

Schnell, R. C. and Vali, G.: Freezing nuclei in marine waters, Tellus, 27, 321-323, doi:10.1111/j.2153-3490.1975.tb01682.x, 1975.

Schroder, J. C., Hanna, S. J., Modini, R. L., Corrigan, A. L., Kreidenwies, S. M., Macdonald, A. M., Noone, K. J., Russell, L. M., Leaitch, W. R., and Bertram, A. K.: Size-resolved observations of refractory black carbon particles in cloud droplets at a marine boundary layer site, Atmos. Chem. Phys., 15, 1367-1383, doi:10.5194/acp-15-1367-2015, 2015.

Schwarz, J. P., Gao, R. S., Spackman, J. R., Watts, L. A., Thomson, D. S., Fahey, D. W., Ryerson, T. B., Peischl, J., Holloway, J. S., Trainer, M., Frost, G. J., Baynard, T., Lack, D. A., de Gouw, J. A., Warneke, C., and Del Negro, L. A.: Measurement of the mixing state, mass, and optical size of individual black carbon particles in urban and biomass burning emissions, Geophys. Res. Lett., 35, L13810, doi:10.1029/2008GL033968, 2008.

Schwarz, J. P., Gao, R. S., Perring, A. E., Spackman, J. R., and Fahey, D. W.: Black carbon aerosol size in snow, Sci. Rep., 3, 1356, doi:10.1038/srep01356, 2013.

Sesartic, A., Lohmann, U., and Storelvmo, T.: Modelling the impact of fungal spore ice nuclei on clouds and precipitation, Environ. Res. Lett., 8, 014029, doi:10.1088/1748-9326/8/1/014029, 2013.
Sivaprakasam, V., Huston, A., Scotto, C., and Eversole, J.: Multiple UV wavelength excitation and fluorescence of bioaerosols, Opt. Express, 12, 4457-4466, doi:10.1364/OPEX.12.004457, 2004.

Sorooshian, A., Padró, L. T., Nenes, A., Feingold, G., McComiskey, A., Hersey, S. P., Gates, H., Jonsson, H. H., Miller, S. D., Stephens, G. L., Flagan, R. C., and Seinfeld, J. H.: On the link between ocean biota emissions, aerosol, and maritime clouds: Airborne, ground, and satellite measurements off the coast of California, Global Biogeochem. Cy., 23, GB4007, doi:10.1029/2009GB003464, 2009.

Spracklen, D. V. and Heald, C. L.: The contribution of fungal spores and bacteria to regional and global aerosol number and ice nucleation immersion freezing rates, Atmos. Chem. Phys., 14, 90519059, doi:10.5194/acp-14-9051-2014, 2014.

Statistics Canada: Catalogue no. 98-316-XWE, available at: http://www12.statcan.gc.ca/census-recensement/2011/dp-pd/ prof/index.cfm?Lang=E (last access: 4 November 2014), Ottawa, 2012.

Storelvmo, T., Hoose, C., and Eriksson, P.: Global modeling of mixed-phase clouds: The albedo and lifetime effects of aerosols, J. Geophys. Res., 116, D05207, doi:10.1029/2010JD014724, 2011.

Sun, J., Ariya, P. A., Leighton, H. G., and Yau, M. K.: Modeling Study of Ice Formation in Warm-Based Precipitating Shallow Cumulus Clouds, J. Atmos. Sci., 69, 3315-3335, doi:10.1175/JAS-D-11-0344.1, 2012.

Szyrmer, W. and Zawadzki, I.: Biogenic and anthropogenic sources of ice-forming nuclei: A review, B. Am. Meteorol. Soc., 78, 209228, 1997.

Tobo, Y., Prenni, A. J., DeMott, P. J., Huffman, J. A., McCluskey, C. S., Tian, G., Pöhlker, C., Pöschl, U., and Kreidenweis, S. M.: Biological aerosol particles as a key determinant of ice nuclei populations in a forest ecosystem, J. Geophys. Res.-Atmos., 118, 10100-10110, doi:10.1002/jgrd.50801, 2013.

Tobo, Y., DeMott, P. J., Hill, T. C. J., Prenni, A. J., SwobodaColberg, N. G., Franc, G. D., and Kreidenweis, S. M.: Organic matter matters for ice nuclei of agricultural soil origin, Atmos. Chem. Phys., 14, 8521-8531, doi:10.5194/acp-14-8521-2014, 2014.

Tsumuki, H., Konno, H., Maeda, T., and Okamoto, Y.: An icenucleating active fungus isolated from the gut of the rice stem borer, Chilo suppressalis Walker (Lepidoptera: Pyralidae), J. Insect Physiol., 38, 119-125, doi:10.1016/0022-1910(92)90040-K, 1992.

Twohy, C. H., DeMott, P. J., Pratt, K. A., Subramanian, R., Kok, G. L., Murphy, S. M., Lersch, T., Heymsfield, A. J., Wang, Z., Prather, K. A., and Seinfeld, J. H.: Relationships of BiomassBurning Aerosols to Ice in Orographic Wave Clouds, J. Atmos. Sci., 67, 2437-2450, doi:10.1175/2010JAS3310.1, 2010.

United States Environmental Protection Agency: Air Emission Sources, http://www.epa.gov/air/emissions/index.htm (last access: 7 April 2015), 2014.

Vali, G.: Quantitative Evaluation of Experimental Results on the Heterogeneous Freezing Nucleation of Supercooled Liquids, J. Atmos. Sci., 28, 402-409, 1971.

Vali, G.: Nucleation Terminology, J. Aerosol Sci., 16, 575-576, doi:10.1016/0021-8502(85)90009-6, 1985. 
Vali, G., DeMott, P. J., Möhler, O., and Whale, T. F.: Technical Note: A proposal for ice nucleation terminology, Atmos. Chem. Phys., 15, 10263-10270, doi:10.5194/acp-15-10263-2015, 2015. von Blohn, N., Mitra, S. K., Diehl, K., and Borrmann, S.: The ice nucleating ability of pollen: Part III. New laboratory studies in immersion and contact freezing modes including more pollen types, Atmos. Res., 78, 182-189, doi:10.1016/j.atmosres.2005.03.008, 2005.

Webster, J. and Weber, R. W. S.: Introduction to Fungi, Third Edition, Cambridge University Press, New York, NY, USA, 2007.

Welti, A., Lüönd, F., Kanji, Z. A., Stetzer, O., and Lohmann, U.: Time dependence of immersion freezing: an experimental study on size selected kaolinite particles, Atmos. Chem. Phys., 12, 9893-9907, doi:10.5194/acp-12-9893-2012, 2012.

Wheeler, M. J. and Bertram, A. K.: Deposition nucleation on mineral dust particles: a case against classical nucleation theory with the assumption of a single contact angle, Atmos. Chem. Phys., 12, 1189-1201, doi:10.5194/acp-12-1189-2012, 2012.

Wheeler, M. J., Mason, R. H., Steunenberg, K., Wagstaff, M., Chou, C., and Bertram, A. K.: Immersion Freezing of Supermicron Mineral Dust Particles: Freezing Results, Testing Different Schemes for Describing Ice Nucleation, and Ice Nucleation Active Site Densities, J. Phys. Chem. A, 119, 4358-4372, doi:10.1021/jp507875q, 2015.

Whitney, F. A., Crawford, W. R., and Harrison, P. J.: Physical processes that enhance nutrient transport and primary productivity in the coastal and open ocean of the subarctic NE Pacific, Deep-Sea Res. Pt. II, 52, 681-706, doi:10.1016/j.dsr2.2004.12.023, 2005.

Wilson, T. W., Ladino, L. A., Alpert, P. A., Breckels, M. N., Brooks, I. M., Browse, J., Burrows, S. M., Carslaw, K. S., Huffman, J. A., Judd, C., Kilthau, W. P., Mason, R. H., McFiggans, G., Miller, L. A., Nájera, J. J., Polishchuk, E., Rae, S., Schiller, C. L., Si, M., Vergara Temprado, J., Whale, T. F., Wong, J. P. S., Wurl, O., Yakobi-Hancock, J. D., Abbatt, J. P. D., Aller, J. Y., Bertram, A. K., Knopf, D. A., and Murray, B. J.: A marine biogenic source of atmospheric ice nucleating particles, Nature, 525, 234-238, doi:10.1038/nature14986, 2015.
Wright, T. P. and Petters, M. D.: The role of time in heterogeneous freezing nucleation, J. Geophys. Res.-Atmos., 118, 3731-3743, doi:10.1002/jgrd.50365, 2013.

Wright, T. P., Petters, M. D., Hader, J. D., Morton, T., and Holder, A. L.: Minimal cooling rate dependence of ice nuclei activity in the immersion mode, J. Geophys. Res.-Atmos., 118, 10535-10543, doi:10.1002/jgrd.50810, 2013.

Yakobi-Hancock, J. D., Ladino, L. A., and Abbatt, J. P. D.: Feldspar minerals as efficient deposition ice nuclei, Atmos. Chem. Phys., 13, 11175-11185, doi::10.5194/acp-13-11175-2013, 2013.

Yakobi-Hancock, J. D., Ladino, L. A., Bertram, A. K., Huffman, J. A., Jones, K., Leaitch, W. R., Mason, R. H., Schiller, C. L., Toom-Sauntry, D., Wong, J. P. S., and Abbatt, J. P. D.: CCN activity of size-selected aerosol at a Pacific coastal location, Atmos. Chem. Phys., 14, 12307-12317, doi:10.5194/acp14-12307-2014, 2014.

Yang, M., Howell, S. G., Zhuang, J., and Huebert, B. J.: Attribution of aerosol light absorption to black carbon, brown carbon, and dust in China - interpretations of atmospheric measurements during EAST-AIRE, Atmos. Chem. Phys., 9, 2035-2050, doi:10.5194/acp-9-2035-2009, 2009.

Yun, Y. and Penner, J. E.: An evaluation of the potential radiative forcing and climatic impact of marine organic aerosols as heterogeneous ice nuclei, Geophys. Res. Lett., 40, 4121-4126, doi:10.1002/grl.50794, 2013.

Zimmermann, F., Weinbruch, S., Schütz, L., Hofmann, H., Ebert, M., Kandler, K., and Worringen, A.: Ice nucleation properties of the most abundant mineral dust phases, J. Geophys. Res., 113, D23204, doi:10.1029/2008JD010655, 2008. 